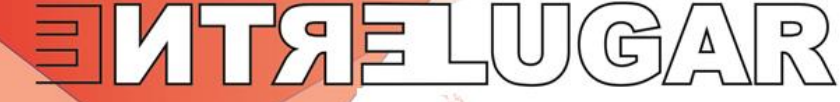

\section{RECENTE DESEMPENHO DA DINÂMICA PRODUTIVA E A DIFUSÂO \\ TERRITORIAL DA AGROPECUÁRIA MARANHENSE}

\section{RECENT PERFORMANCE OF PRODUCTIVE DYNAMICS AND THE TERRITORIAL DIFFUSION OF MARANHANESE}

\section{RENDIMIENTO RECIENTE DE DINÁMICA PRODUCTIVA Y LA DIFUSIÓN TERRITORIAL DE MARANHANESE}

\begin{abstract}
Roberto César Costa Cunha
Mestre em Geografia e doutorando em Geografia pela Universidade Federal de Santa Catarina (UFSC).
\end{abstract}

robertoujsma@hotmail.com

\section{RESUMO}

A agropecuária no estado do Maranhão constitui-se em um dos principais setores econômicos geradores da economia estadual. Entre 2009-2018, o Valor Bruto da Produção dos principais produtos da agropecuária do Maranhão cresceu de R \$ 5,1 bilhões para R \$ 7,6 bilhões. Nas exportações, o valor gerado em 2018, foi de US\$1,9 bilhão, o que representa $51 \%$ do valor total do estado, e $2 \%$ do valor total da agropecuária brasileira. Desse modo, como a agropecuária no estado do Maranhão, com ocorrência inequívoca, conseguiu dar um impulso dinâmico na sua estrutura de produção e difundir-se territorialmente? Assim sendo, a resposta para esse questionamento central é objetivada na identificação do desempenho produtivo da agropecuária do estado com base nos indicadores de área plantada, valor bruto da produção, produtividade e participação na pauta exportadora. Para alcançar essa resposta, usou-se a categoria formação socioespacial como método de análise. Toda essa performance veio acompanhada da irresignação significativa das estruturas produtivas das mesorregiões através dos processos de: concentração, desconcentração, especialização, disseminação e exclusão territoriais.

Palavras-chave: Desempenho produtivo; Estruturas produtivas territoriais. Diferenciação regional.

\begin{abstract}
Farming in the state of Maranhão is one of the main generating economic sectors of the state economy. Between 2009-2018, the Gross Production Value of Maranhão's main agricultural products grew from $\mathrm{R} \$ 5.1$ billion to $\mathrm{R} \$ 7.6$ billion. In exports, the value generated in 2018 was US $\$ 1.9$ billion, representing $51 \%$ of the total value of the state, and $2 \%$ of the total value of Brazilian agriculture. In this way, how has agriculture, in the state of Maranhão, with an unambiguous occurrence, managed to give a dynamic impetus in its production structure and spread territorially? Thus, the answer to this central question is aimed at identifying the productive performance of the state's
\end{abstract}

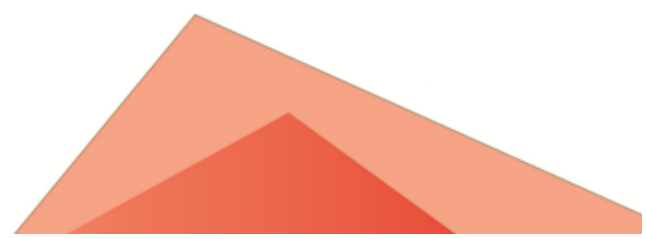




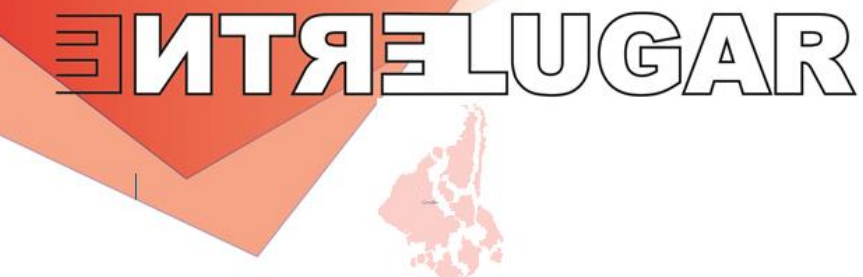

agriculture based on the indicators of planted area, gross production value, productivity and participation in the export agenda. To achieve this answer, the socio-spatial training category was used as a method of analysis. All this performance was accompanied by the significant disrespect of the productive structures of the mesoregions through the processes of: concentration, deconcentration, specialization, dissemination and territorial exclusion.

Keywords: Productive performance; Territorial productive structures; Regional differentiation.

\section{RESUMEN}

La agricultura en el estado de Maranhão es uno de los principales sectores económicos generadores de la economía estatal. Entre 2009-2018, el valor de producción bruto de los principales productos agrícolas de Maranhão aumentó de $\mathrm{R}$ \$ 5,1 mil millones a $\mathrm{R}$ \$ 7,6 mil millones. En exportaciones, el valor generado en 2018 fue de US \$ 1.9 mil millones, lo que representa el $51 \%$ del valor total del estado y el $2 \%$ del valor total de la agricultura brasileña. De esta manera, ¿cómo ha logrado la agricultura, en el estado de Maranhão, con una ocurrencia inequívoca, dar un ímpetu dinámico en su estructura de producción y extenderse territorialmente? Por lo tanto, la respuesta a esta pregunta central apunta a identificar el desempeño productivo de la agricultura del estado con base en los indicadores de área plantada, valor de producción bruta, productividad y participación en la agenda de exportaciones. Para lograr esta respuesta, la categoría de entrenamiento socioespacial se utilizó como método de análisis. Todo este desempeño estuvo acompañado por la falta de respeto significativa de las estructuras productivas de las mesorregiones a través de los procesos de concentración, desconcentración, especialización, difusión y exclusión territorial.

Palabras-clave: Desempeño productivo; Estructuras productivas territoriales;

Diferenciación regional.

\section{INTRODUÇÃO}

Com uma área de 329,6 mil km², o equivalente a 3,8\% do território brasileiro, e uma população total em torno de 7,07 milhões de habitantes, sendo $64 \%$ desse total vivendo em áreas urbanas (IBGE, 2020f), o estado do Maranhão é uma das principais economias na estrutura produtiva do Nordeste brasileiro. Em 2017, o Produto Interno Bruto (PIB) do Maranhão foi de R \$ 89,5 bilhões, o que correspondeu a 9,4\% e 1,36\% do total do valor gerado no Nordeste e no Brasil, respectivamente (IBGE, 2020d). Nas

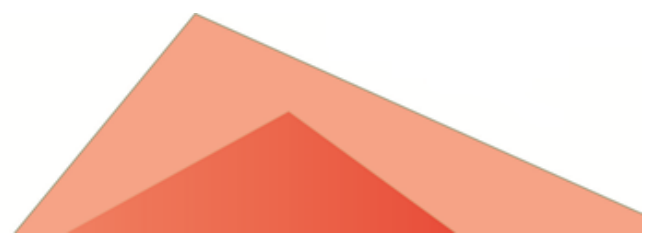




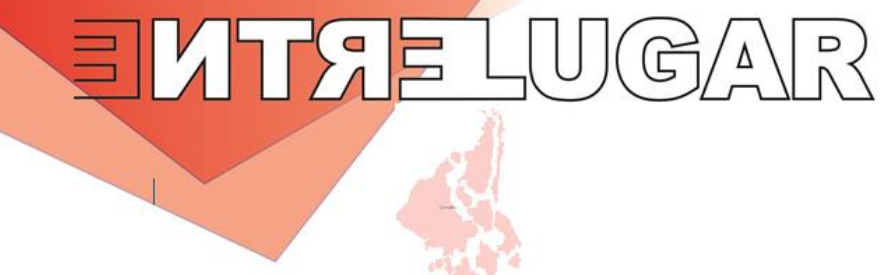

exportações, participa com 1,9\%, cerca de US\$ 3,8 bilhões, do total exportado pela economia brasileira (BRASIL, 2020a).

Apesar de o setor de serviços ter apresentado um grande crescimento nas últimas décadas, a economia do Maranhão é impulsionada pela agropecuária e a indústria de transformação. Com 219,7 mil estabelecimentos rurais e uma população rural de 2,45 milhões de pessoas (IBGE, 2020e), o valor bruto de produção ${ }^{1}$ (VBP) da agropecuária do Maranhão foi de R \$ 7,6 bilhões, em 2018, sendo 22,3\% oriundos da pecuária e $77,6 \%$ da agricultura (BRASIL, 2020c). Em seu conjunto, a agropecuária representa $11 \%$ da estrutura econômica e foi responsável por $50 \%$ das receitas das exportações (BRASIL, 2020b).

Atualmente, o Maranhão possui o quinto market share (participação no mercado) de todo o arroz em casca do Brasil, a sexta colocação da produção de mandioca, o nono lugar na produção nacional de soja. Regionalmente, o estado maranhense possui a segunda produção de algodão e sorgo, o quarto lugar colheita da cultura de feijão, a terceira produção de milho, a sexta quantidade produzida de canade-açúcar (IBGE, 2020a). Na pecuária, o Maranhão se destaca nacionalmente no efetivo do rebanho bovino com mais de 7,7 milhões de cabeças. No Nordeste, o estado possui o maior efetivo bubalino com mais de $71 \%$ do total e o segundo lugar na criação de

\footnotetext{
${ }^{1}$ É a expressão monetária da soma de todos os bens e serviços produzidos em determinado território econômico, num dado período de tempo. O Valor Bruto da Produção Agropecuária representa uma estimativa da geração de renda do meio rural, revertendo em uma variável relevante para acompanhamento do desempenho do setor na sua íntegra. O Valor Bruto da Produção Agropecuária mostra a evolução do desempenho das lavouras e da pecuária ao longo do ano e corresponde ao faturamento bruto dentro do estabelecimento; é calculado com base na produção da safra agrícola e da pecuária, e nos preços recebidos pelos produtores nas principais praças do país, dos 26 maiores produtos agropecuários do Brasil. A estimativa do VBP é elaborada pela Coordenação-Geral de Estudos e Análises (CGEA) do Departamento de Crédito e Estudos Econômicos (DCEE), da Secretaria de Política Agrícola (SPA) do Ministério da Agricultura, Pecuária e Abastecimento (MAPA) (BRASIL, 2018b). No entanto, Faria (1983, p. 109-110) assinala que esse agregado macroeconômico pode trazer distorções, como a dupla contagem, por exemplo. Diante disso, elaborou-se o "conceito de Valor adicionado Bruto (VAB), que é utilizado como medida da riqueza social gerada em uma região ou país em determinado período. A definição do VAB é dada pela diferença entre o VBP e o consumo intermediário $(\mathrm{Cl})$. Isto é, o valor de todas as mercadorias que entram na produção de outras mercadorias é descontado do valor total das mercadorias produzidas". No texto, optou-se em utilizar VBP para o Brasil e o estado do Maranhão, e VAB para as mesorregiões do estado, para minimização das distorções regionais.
}

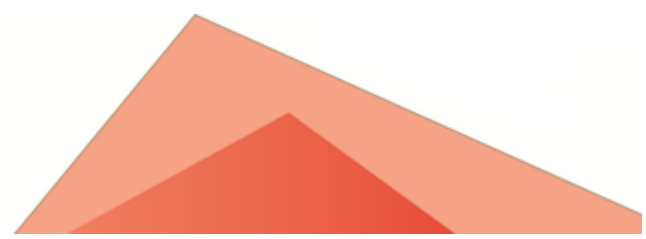




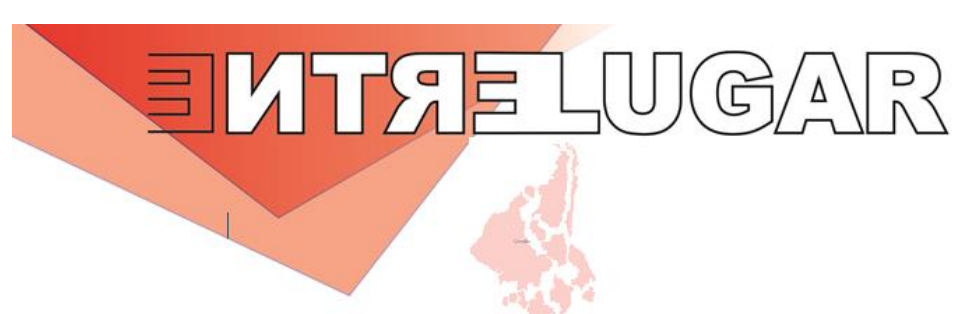

equinos perdendo apenas para o estado da Bahia. Na criação de frango, o Maranhão possui mais de 12,1 milhões de cabeças e no rebanho suíno sua competitividade atinge 1,03 milhão de cabeças. Além disso, na produção de produtos de origem animal destaca-se: leite e mel de abelha (IBGE, 2020b). Ademais, no extrativismo vegetal, salienta-se a produção de amêndoas de coco babaçu com 92,8\% do total nacional, e na silvicultura, o estado está na segunda colocação da produção nacional de carvão vegetal com mais 380 mil toneladas (IBGE, 2020c).

Diante do dinamismo e representatividade da agropecuária maranhense surge um questionamento: como a agropecuária no estado do Maranhão conseguiu dar um impulso dinâmico na sua estrutura de produção e espraiar-se territorialmente? Disto posto, o artigo tem como objetivo principal desvendar o desempenho produtivo e as alterações ocorridas nas estruturas regionais de produção pós- $2003^{2}$. Para atingir esse objetivo, usou-se a categoria formação socioespacial ${ }^{3}$ elaborada por Santos (1977), bem como a ideia de combinações geográficas de Cholley (1964) ${ }^{4}$. Segundo Santos (1977), uma formação socioespacial é uma realidade concreta, que se transforma, evolui e muda com o processo histórico. Trata-se de uma categoria das totalidades históricas e que deve ser considerada como expressão socioespacial dos processos que se singularizam em virtude de determinadas combinações. Didaticamente, a formação socioespacial é

\footnotetext{
2 Justificam-se os anos pós-2003, em razão de a economia brasileira ter desenvolvido um ciclo de crescimento condicionado por fatores internos e externos. Internamente os investimentos foram assentados em três frentes (infraestrutura, recursos naturais e consumo de massa). Externamente, contribuíram a liquidez financeira mundial, a taxa de juros baixa no mundo, os investimentos externos diretos e a elevada demanda mundial por produtos agroalimentares e minerais (ESPÍNDOLA; 2016; BIELSCHOWSKY, 2013; BARBOSA, 2013).

${ }^{3} \mathrm{O}$ interesse do artigo é recuperar a categoria formação socioespacial como possibilidade de ser um mecanismo eficiente para interpretar a realidade da agricultura brasileira e de suas regiões.

${ }^{4}$ Conforme Cholley (1964), essas combinações podem ser de três tipos: (i) aquelas que convergem de fatores físicos (a geomorfologia, a hidrologia, etc.); (ii) aquelas de complexidade maior de ordem física e de ordem biológica (o cerrado); e (iii) aquelas de ordem tridimensional, mais complicadas e muito mais requintadas de detalhes, de ordens físicas, biológicas e humanas (agricultura, indústria, comércio). Essas combinações geográficas ampliam as possibilidades das análises, pois a realidade é fruto da relação dialética entre os aspectos naturais e humanos. Essas relações são estabelecidas em múltiplas escalas (mundial, nacional, regional e local), e permitem compreender um determinado objeto de estudo num universo mais amplo. Para uma combinação ser originalmente geográfica, é necessário que ela interfira na totalidade de um grupo humano, pois o caráter geográfico está determinado pela relação espaço e tempo. Um determinado sistema agrícola é composto por combinações geográficas mais complexas, pois resultam da interação de elementos físicos (solo, clima, etc.), elementos biológicos (flora) e elementos humanos (máquinas e mão de obra). Assim, o homem, para escolher um determinado cultivo e as técnicas mais adequadas, tem de observar as condições naturais que o cercam para obter as colheitas necessárias à sua sobrevivência.
}

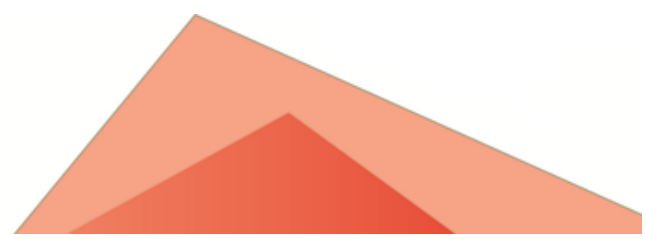




\section{- MTGE LUGAR}

uma realidade concreta histórica e geograficamente localizada. Assim, cada formação socioespacial é singular, na qual os processos gerais interagem com as características particulares, gerando combinações geográficas específicas.

Tendo em vista da capacidade produtiva no interior da agropecuária, procurou-se destacar o desempenho das atividades dentro da porteira, com relevo para as lavouras temporárias e a pecuária. Para tanto, foram selecionados os principais produtos com representatividade na produção, área plantada, VBP, rentabilidade e participação na pauta exportadora maranhense. Ainda do ponto de vista metodológico, utilizou-se a divisão mesorregional do estado do Maranhão definida pelo Instituto Brasileiro de Geografia e Estatística (IBGE).

No texto, optou-se pela agropecuária (lavouras e criações), pois caracterizou-se significativa especialização e diferenciação mesorregional, com diversos territórios produtivos dominados pelas culturas de grãos e pelos rebanhos que outrora não exerciam essas funções. As abordagens territoriais são necessárias, pois

"o complexo produtivo da agricultura desenvolveu-se com a formação de inúmeros segmentos produtivos com estruturas produtivas para mais além dos limites da agropecuária, rompendo com a concepção rural ao formar cadeias de produção que não mais se explicam pela dicotomia campo-cidade. A emancipação de atividades antes internas às propriedades rurais, que passaram a se constituir em novos ramos das cadeias de produção, fez a agropecuária perder espaço relativo no complexo produtivo dos agronegócios da agricultura. Nesse processo em que cada vez mais a produção passou a ser cada vez menos fruto da terra e do trabalho do homem", na acepção bíblica cristã, não apenas o trabalho foi potencializado e perdeu espaço para a mecanização e automação, mas também a terra perdeu espaço para a fertilização, correção e genética, que impulsionaram a produtividade da terra. A agropecuária moderna pode ser feita com menos terra $\mathrm{e}$ menos trabalho, mas com muito mais capital, estando inserida na lógica de expansão da reprodução ampliada do capital. O complexo de agronegócios da agricultura pode ser visualizado como uma estrutura de segmentos setoriais na qual a produção biológica passa a ser veículo estratégico para a combinação de insumos e instrumentos gerados fora dos campos e a ser fornecedora de bens intermediários para estruturas de agregação de valor, envolvendo empreendimentos em cadeias que se iniciam nas fábricas de insumos e maquinaria e finalizam-se nas estruturas de varejo" (GONÇALVES, 2005, p. 1011).

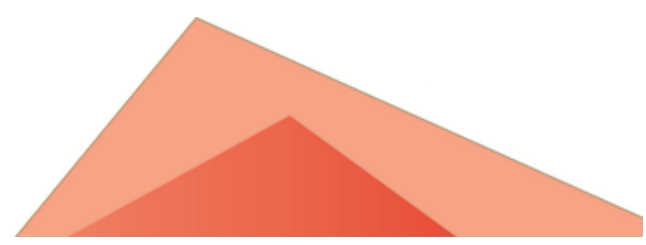


Dessa maneira, diferentemente de uma vasta bibliografia que associa agronegócio à produção de commodities e o tamanho da área, define-se, aqui, os agronegócios como uma cadeia produtiva "que envolve desde a fabricação de insumos, passando pela produção nos estabelecimentos agropecuários, pela transformação e o seu consumo final" (CONTINI et al., 2006, p. 6). Para o conjunto das atividades dos agronegócios, existe uma diversidade de os segmentos. Esses segmentos dividem-se em: (1) pré-porteira (indústrias de bens de capital e indústrias químicas e de embalagens; (2) dentro da porteira (agropecuária que corresponde às lavouras permanentes, lavouras temporárias, extrativismo vegetal, e produção pecuária), e (3) pós-porteira (agrosserviços).

Na elaboração deste artigo, optou-se pela abordagem exploratória (GIL, 1994), que adota a busca de informações a respeito de certo assunto e envolve o levantamento bibliográfico e documental, com base em fontes primárias, secundárias e pesquisas de campo $^{5}$. Foram feitas análises de diferentes artigos, livros e teses, visando avaliar e situar a bibliografia relativa à temática exposta ${ }^{6}$.

O levantamento de dados estatísticos foi realizado nos relatórios da Produção Agrícola Municipal (PAM) e no Levantamento Sistemático da Produção Agrícola (LSPA), e em censos agropecuários ofertados pelo IBGE. Buscaram-se, ainda, informações publicadas nos relatórios do Ministério da Agricultura, Pecuária e Abastecimento (MAPA), nos relatórios técnicos do Ministério do Desenvolvimento da Indústria e do Comércio Exterior (MDIC).

Por fim, estruturalmente, o texto está dividido, afora da introdução e das considerações finais, em mais três partes, abordando: (i) uma síntese da ocupação territorial às transformações nas estruturas agropecuárias maranhenses; (ii) o desempenho da produção e da exportação dos principais produtos da agropecuária do estado; (iii) e o novo arranjamento territorial da agropecuária do Maranhão.

\footnotetext{
${ }^{5}$ Foram feitas inúmeros pesquisas de campo pelo autor, sobretudo no Sul do Maranhão, entre setembro de 2013 a dezembro de 2019.

${ }^{6}$ Uma revisão da literatura para melhor compreensão do problema, mesmo que exista a possibilidade de essa não esteja devidamente ajustada ao objetivo do artigo, serve para dimensionamento progressivo ao entendimento ao temário proposto, uma vez que, o propósito é completar a cognoscibilidade, sobretudo do autor, da transformação de dados da realidade concreta em conhecimento.
} 


\section{DA OCUPAÇÃO TERRITORIAL ÀS TRANSFORMAÇÕES NAS ESTRUTURAS AGROPECUÁRIAS MARANHENSES: UMA SÍNTESE}

Dentro das combinações geográficas pode-se, sinteticamente, afirmar que o processo de ocupação e desenvolvimento do estado do Maranhão (Figura 1) originou-se em duas macroentradas territoriais. A primeira entrada, na parte norte, deriva da concorrência comercial das monarquias feudais europeias, dada por São Luís, que logo transformou-se num entreposto comercial. Com estímulos da Coroa Portuguesa, a ocupação deu-se através da subida do vale do rio Itapecuru, Mearim, Pindaré e Munim, adentrando a mata dos Cocais, e na mata de pré-amazônica. Com isso, originou uma estrutura socioespacial pautada em forças produtivas ligadas a agricultura, com relações de produção escravistas.

A segunda entrada, na parte sul, vindo principalmente da Bahia, sertanejos e vaqueiros vieram tocando gado em busca de pasto, ultrapassaram o Rio Parnaíba e chegaram no cerrado. Região ideal para pecuária do gado crioulo. De fazenda em fazenda, foram ocupando todo sul do estado. A partir disso surgiu a uma estrutura socioespacial formada por forças produtivas apoiadas em atividades pecuárias e com relações sociais de esboço feudal.

Figura 1 - Localização do estado do Maranhão
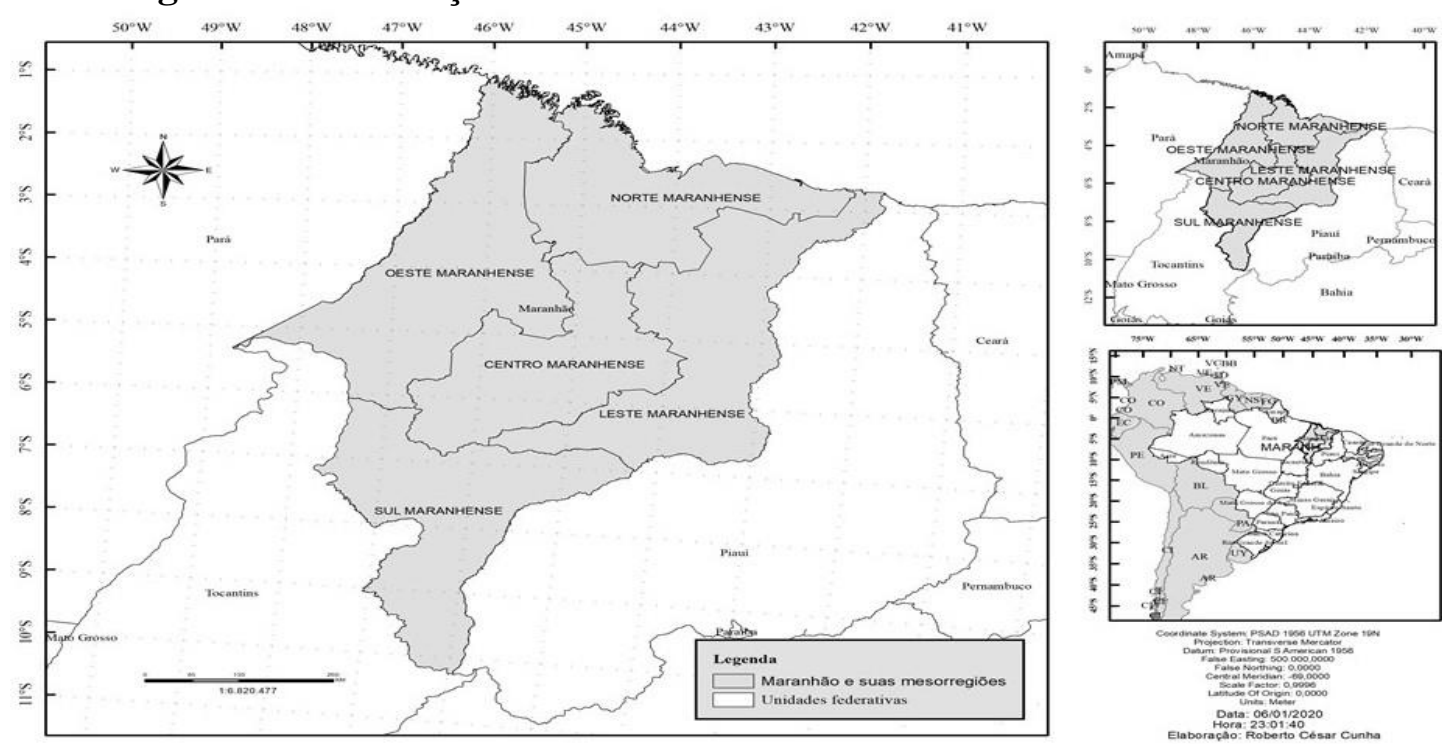

Fonte: IBGE. Elaboração: autor

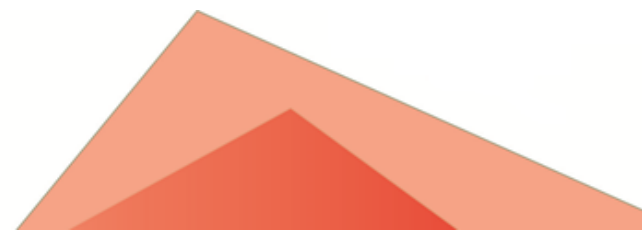


Nessa primeira macroentrada, em primeira fase, na planície litorânea, a Coroa Portuguesa $^{7}$ fez uma primeira intervenção. Inseriu, em 1620, cerca de 840 casais de colonos açorianos (COUTINHO, 2004; MEIRELES, 1960). A alta fertilidade dos vales dos rios, o solo plano, abundância de terras cultiváveis, ajudaram organizar uma economia natural a base de uma produção policultora (farinha de mandioca, aguardente, arroz, vegetais e etc.), a pesca e criação de animais pequenos.

Numa segunda fase, a Coroa Portuguesa fez outra intervenção na ocupação da área litorânea. Ocorreu na metade do XVIII, sob a liderança do Marquês de Pombal, que: trocou a escravidão indígena pela negra; expulsou os jesuítas; criou a Companhia Geral do Grão Pará e Maranhão (CGGPM) (MEIRELHES, 1960). A CGGPM passou a aplicar uma engenhosa política de preços, trouxe mestres agricultores da Europa e a fornecer créditos aos agricultores para comprarem escravos negros, instrumentos e ferramentas de produção, sementes de qualidade de algodão e arroz, mais tarde cana-deaçúcar. Em síntese as duas etapas de ocupação do norte do Maranhão tiveram fundamental ajuda da Coroa Portuguesa. Assim, gerou uma estrutura econômica e social com forças produtivas principalmente ligadas à agricultura (algodão, arroz e cana-deaçúcar), pautada na grande propriedade privada, com relações de produção apoiada na escravidão dos índios e dos negros africanos, firmando uma miscigenação de portugueses, índios e africanos.

A segunda macroentrada deriva da alta rentabilidade da produção da cana-deaçúcar, que levou essa cultura à uma especialização, e foi a causa essencial na expansão da pecuária nordestina, pois a carne e o couro eram complemento fundamentais na economia canavieira (FURTADO, 2007). A expansão pastoril no sertão nordestino passou por três etapas de fixação: na primeira, a partir da cana-de-açúcar, o gado era essencial na propriedade de escravos como alimento para mão-de-obra, como transporte a tração animal na circulação de pequenas e médias distancias e como força na moenda;

\footnotetext{
7 Antes dessa primeira intervenção da Coroa Portuguesa no Brasil, o Maranhão foi invadido pelos franceses, pois tinham o interesse de fundar uma colônia no norte do Brasil (França Equinocial) (VIVEIROS, 1954). Os franceses se apropriaram da mão de obra dos índios Tupinambás, construíram algumas feitorias, um armazém e um forte de madeira, organizaram produção de vários gêneros. Porém, os portugueses expulsaram os franceses invasores na famosa batalha de Guaxenduba.
}

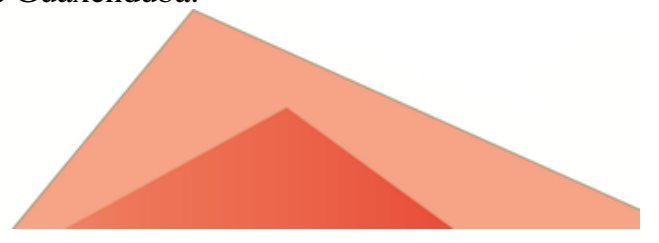


na segunda, com o crescimento dos rebanhos gerou a incompatibilidade entre as duas culturas e a separação da propriedade agrícola e a propriedade pastoril; e, por sua vez, a total diferenciação das duas culturas, a expansão geográfica do interior - da Bahia ao Maranhão - se tornou necessária, pois as trocas internas entres as áreas pastoris, áreas agrícolas e áreas mineradoras se intensificaram. A propriedade da terra se expandiu e gerou relações feudais de produção pela sua incompatibilidade nas relações escravistas.

No início do século XVIII, chegaram nos sertões do Maranhão os primeiros vaqueiros baianos irradiados do vale do rio São Francisco que conseguiram romper a barreira natural do rio Parnaíba. Logo vendo a imensidão dos verdes pastos maranhenses, pois nunca avistados na caatinga nordestina, batizaram a região com o nome de pastos bons, e logo fundaram uma vila com mesmo nome, na chapada nordeste da serra do Itapecuru (CARDOSO, 1947). As transações comerciais se intensificaram através das vias de acumulação Rio Grajaú e Rio Mearim até São Luís e, consequentemente, aumentou a densidade populacional. Esse incremento comercial atrairia pessoas em busca de novas terras para a atividade pastoril e/ou para se esconder da polícia ou de perseguições políticas (CARVALHO, 1924).

Para simplificar, verificou-se que essa segunda entrada se formou uma estrutura econômica e social apoiada em forças produtivas ligado a pecuária e relações de produção apoiada num conjunto de renda trabalho e renda produto ${ }^{8}$. A ocupação do Maranhão submete-se à influência de elementos naturais, político-culturais e econômicos, que contribuíram para gerar duas estruturas socioespaciais homogêneas quanto à fixação humana e uma diferenciação quanto à forma de produzir. Um imbricamento de vários modos de produzir com diversas relações de produção.

Sendo assim, no Norte, houve um espraiamento do algodão nos vales: Itapecuru; Munim; Mearim; Pindaré. Esta cultura representava $70 \%$ de toda exportação do Maranhão (VIVEIROS, 1954), e o vale do Itapecuru, era responsável por mais da metade da produção (PRADO JR, 2011). No sul do Maranhão, os comerciantes compravam o gado no sertão, transformavam grande parte em carne-seca e peles e as remetia para São Luís e outros centros consumidores. A carne do gado abastecia o

${ }^{8}$ Castro (1980), Abreu (1982) e Prado Jr (2011) trazem uma caracterização fortuita dessas relações produtivas apoiada nas rendas trabalho e produto do estado. 
mercado interno, seus derivados, eram pautados à exportação (ANDRADE, 1995; PRADO JR, 2011).

No início século XX o Maranhão passou pelo período "de ouro" em sua economia, mesmo com um não raro isolamento com o restante do país, vivia intensamente o comércio com a coroa ibérica. O Norte, nas finais décadas do século XIX e nas primeiras do século XX, forjou-se um parque industrial têxtil de maior estatura (RANGEL,2008, p.58). O sul do Maranhão, a partir de 1960, começava a se acelerar a mudança da agricultura de subsistência, de baixa produtividade, para uma agricultura especializada, inserida no mercado e sujeita a melhorias técnicas crescentes. Com a chegada dos pioneiros produtores oriundos do Centro-Sul do Brasil, a partir do início dos anos de 1970, surgiu uma agricultura moderna de arroz e, em seguida, da soja voltada às exportações e ao mercado interno (MALUF, 1977). Disso tudo, forjou-se uma importante lavoura de grãos que atrai muitos investimentos, tantos na atividades pré-porteira como nas atividades dentro da porteira e pós-porteira ${ }^{9}$. Com suporte dessa síntese, na próxima seção veremos o desempenho recente da agropecuária do Maranhão.

\section{DESEMPENHO DA PRODUÇÃO E DA EXPORTAÇÃO DOS PRINCIPAIS PRODUTOS DA AGROPECUÁRIA MARANHENSE}

Conforme IBGE (2020d), o PIB estadual do Maranhão em 2017 atingiu R \$ 89,5 bilhões a preços correntes, que representa 1,36\% do PIB nacional e 9,4\% do PIB do Nordeste. Entre 2003 e 2017, o crescimento acumulado foi de 70 bilhões de reais. Na agropecuária, constata-se a fundamental importância na geração de receita na economia do estado. Nos últimos dez anos, o VBP na agropecuária passou de $\mathrm{R} \$ 4,9$ bilhões, em 2009, para R \$ 7,6 bilhões, em 2018, o que representa um crescimento da ordem de 64,4\% (BRASIL, 2020c).

\footnotetext{
9 Para uma leitura mais detalhada sobre a ocupação e o desenvolvimento das estruturas produtivas do Maranhão ver Cunha (2015). Ainda, para compreender melhor as transformações técnico-produtivas das estruturas agropecuárias maranhenses ver Cunha; Espindola (2015; 2016b).
}

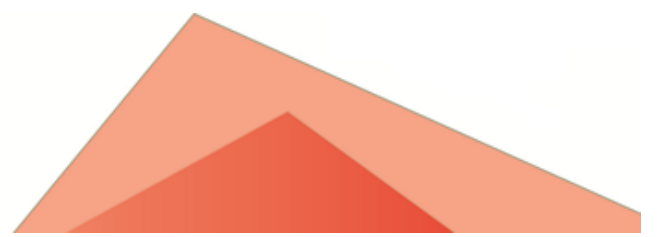


Assim, o valor gerado de mais de R \$ 7,6 bilhões, em 2018, representou 1,3\% de todo o VBP pela agropecuária brasileira. No mesmo ano, o VBP das lavouras maranhenses atingiu $\mathrm{R} \$ 5,9$ bilhões, que cooperava com 1,5\% dos $\mathrm{R} \$ 383,3$ bilhões gerados nas lavouras brasileiras. Na pecuária, o VBP, entre 2009 e 2018, aumentou de $\mathrm{R}$ \$ 1,3 bilhão para $\mathrm{R}$ \$ 1,7 bilhão, correspondendo a quase $1 \%$ do total dos $\mathrm{R} \$ 185,8$ bilhões da pecuária nacional (BRASIL, 2020c).

Desse modo, quando se desmembra o VBP (Figura 2), vê-se que o total do valor gerado pelas lavouras temporárias cresceu de $\mathrm{R} \$ 1,2$ bilhão para $\mathrm{R} \$ 4,8$ bilhões, significando um crescimento real de quatro vezes ( $\mathrm{R} \$ 3,6$ bilhões). Esses valores representaram, em 2018, 15,7\% de todo VBP nordestino ${ }^{10}$.

Figura 2 - Valor Bruto da Produção das lavouras no estado do Maranhão (em R\$ 1000)

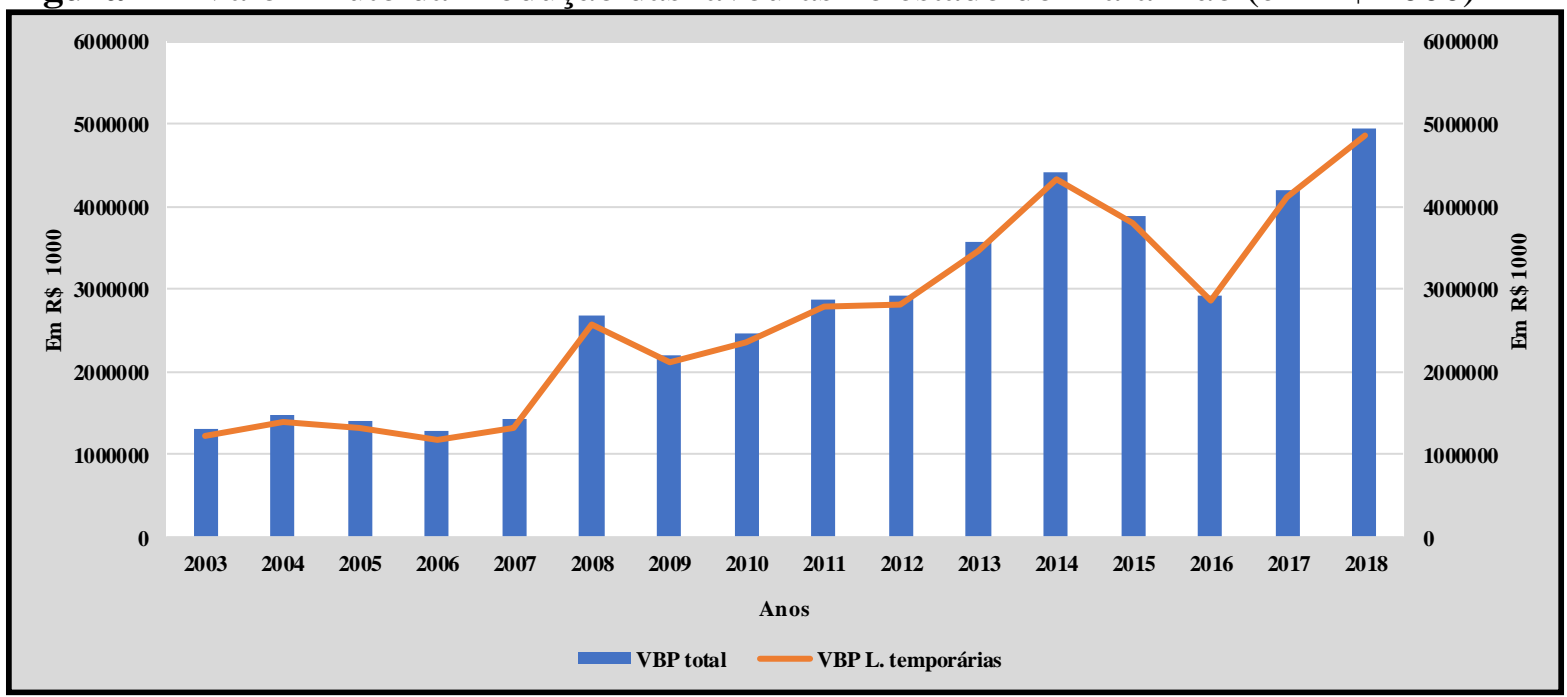

Fonte: BRASIL (2020c). Elaboração: autor

No que diz respeito aos produtos específicos das lavouras temporárias, consoante a Figura 3, o VBP da cultura de soja no estado maranhense passou de R $\$ 397,2$ milhões, em 2003, para R \$ 3,1 bilhões, em 2018. Essa expansão representou 680\%, vale dizer, 7,8 vezes, o que lhe concerne uma representação de 2,5\% do VBP do total dessa

10 No referente ao VBP nas lavouras permanentes, o estado do Maranhão representa não pouca insignificante perante o quadro nacional e regional. Entre 2009 e 2018, as receitas geradas passaram de R \$ 84,3 milhões para R\$ 94,4 milhões (BRASIL, 2020c). Entre outros fatores, esse fraco dinamismo está associado ao um forte tradicionalismo cultural e nas técnicas rudimentares de manejo agrícola.

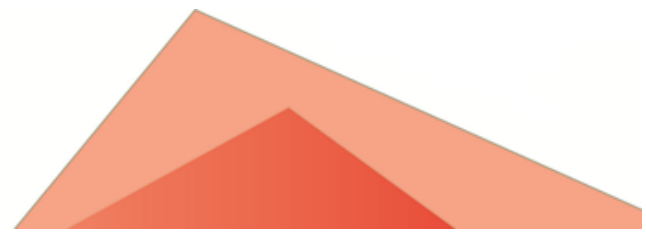


cultura no Brasil ( $\mathrm{R} \$ 127,5$ bilhões), consolidando o estado como nono produtor de soja nacional e o segundo VPB do Nordeste, perdendo apenas para Bahia. Assinala-se, igualmente, o crescimento da receita auferida na produção de milho, no período em tela, de $\mathrm{R} \$ 138,4$ milhões para $\mathrm{R} \$ 723$ milhões, totalizando uma adição de 422\% (5,2 vezes). Com isso, o estado representa 1,93\% do VBP da milhocultura nacional ( $\mathrm{R} \$ 37,6$ bilhões) e 22,2\% na regional (R $\$ 3,2$ bilhões). Nas lavouras de arroz, a renda auferida representou 5,3\% do VBP do Brasil (R \$ 8,5 bilhões) e 49,4\% do VBP da Região Nordeste, contudo, cadeia produtiva que sofreu deterioração na arrecadação estadual de VBP. Em 2003, saiu de $\mathrm{R}$ \$335,9 milhões para $\mathrm{R}$ \$ 162,9 milhões, em 2018, somando decréscimo de 48,4\%.

Figura 3 - Valor Bruto da Produção dos produtos das lavouras temporárias no Maranhão (em $\mathrm{R} \$ 1000)$

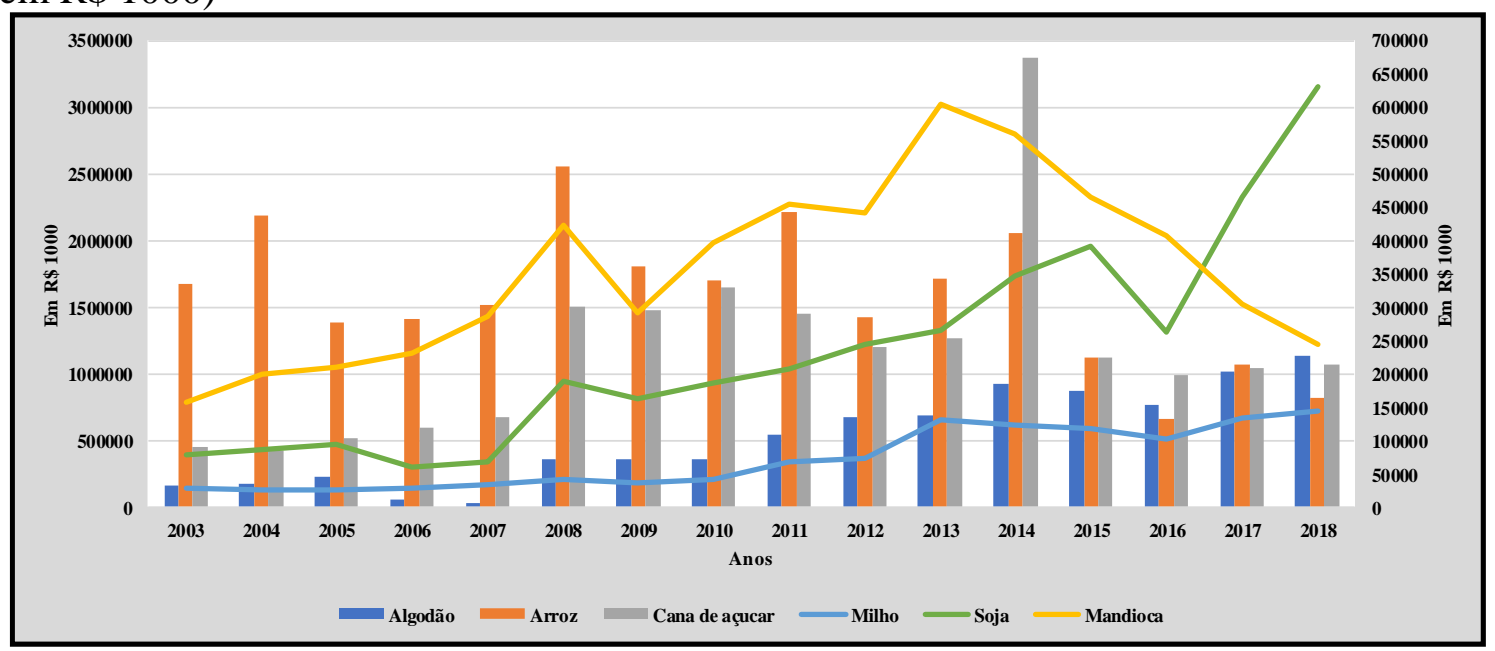

Fonte: BRASIL (2020c). Elaboração: autor

As plantações de cana-de-açúcar também ganham destaque pelo crescimento das receitas no período entre 2003 e 2018, ainda na Figura 3. Tal cultivo sai de R\$91,2 milhões para $\mathrm{R} \$ 213,9$ milhões, acumulando liquidez de 134,5\% (2,3 vezes). Nas lavouras de mandioca, assim como o arroz, houve dinâmica declinante na liquidez do VPB, sobretudo nos últimos cinco nas da série temporal. O VBP em 2003 era de 157, 5 milhões e em 2013 saltou para R \$ 605,1 milhões, todavia, em 2018 apresentou R 244,8 milhões, registrando uma queda, em cinco anos, de 59,6\%. A cotonicultura passou de R\$

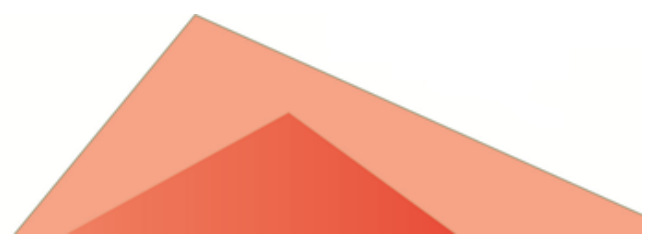


32,7 milhões para $\mathrm{R} \$ 226,6$ milhões, fechando o intervalo de tempo com evolução de $593 \%$, ou seja, quase sete vezes mais ${ }^{11}$.

Essa dinâmica positiva do VBP nas lavouras do Maranhão, com exceção do arroz e da mandioca, harmonizou-se com o aumento da área plantada das culturas temporárias, conforme esclarece a Tabela 1. Entre 2003 e 2018, o alargamento da área cultivada ficou na casa de 387 mil hectares (27,3\%), passando de 1,41 milhão de hectares para 1,8 milhão hectares. Essa expansão significativa aconteceu, principalmente, na área plantada de soja, saindo, do início do período em quadra, de 275 mil hectares para 926 mil no final, acumulando uma alta de 236,7\%, com adição de terras cultivadas de 651 mil hectares. A diferença entre o acréscimo da área da soja para área total das lavouras temporárias alcançou 264 mil hectares, isso porque as culturas do arroz, da mandioca e do abacaxi obtiveram dilatações negativas de área plantada, respectivamente: 74\% (371 mil hectares); 50,9\% (84 mil hectares); 22,1\% (419 hectares). No algodão e nas lavouras de cana-de-açúcar, o aumento em terras plantadas foi, pela ordem: 19 mil e 17,4 mil hectares.

Tabela 1 -Maranhão- área plantada, produção e produtividade (2003-2018)

\begin{tabular}{l|r|r|r|r|r|r|r|r}
\hline & $\mathbf{2 0 0 3}$ & $\mathbf{2 0 0 6}$ & $\mathbf{2 0 1 0}$ & $\mathbf{2 0 1 2}$ & $\mathbf{2 0 1 4}$ & $\mathbf{2 0 1 6}$ & $\mathbf{2 0 1 8}$ \\
\hline \multicolumn{7}{|c|}{ Área plantada (em hectares) } \\
\hline L. temporárias & 1413738 & 1608870 & 1729552 & 1795760 & 1975258 & 1571680 & 1800707 \\
\hline L. permanentes & 31821 & 36094 & 37584 & 34430 & 31128 & 26171 & 26159 \\
\hline Arroz & 501964 & 507446 & 481544 & 431531 & 389418 & 168407 & 130386 \\
\hline Algodão & 3254 & 7194 & 13030 & 18626 & 18588 & 20913 & 22342 \\
\hline Cana-de-açúcar & 27920 & 39301 & 50477 & 49534 & 46810 & 45633 & 45399 \\
\hline Mandioca & 165202 & 212096 & 210060 & 196564 & 188080 & 130908 & 81116 \\
\hline Milho & 359550 & 366513 & 382814 & 451900 & 551885 & 334109 & 414809 \\
\hline Soja & 275252 & 383284 & 495756 & 556178 & 677540 & 783654 & 926656 \\
\hline Banana & 11790 & 11605 & 10924 & 10119 & 9832 & 6941 & 6559 \\
\hline Abacaxi & 1889 & 1418 & 1218 & 1173 & 1388 & 1726 & 1470 \\
\hline \multicolumn{7}{|c|}{ Produção (em toneladas) } & & \\
\hline Arroz & 689051 & 702224 & 589945 & 439143 & 586998 & 152216 & 206977 \\
\hline Algodão & 10564 & 18611 & 42855 & 75059 & 76249 & 66690 & 91654 \\
\hline Cana-de-açúcar & 1703087 & 2306456 & 3176531 & 3011709 & 2665104 & 2520500 & 2427984 \\
\hline Mandioca & 1241190 & 1720322 & 1540586 & 1529579 & 1619342 & 1073966 & 681018 \\
\hline
\end{tabular}

11 Ainda as lavouras temporárias do estado do Maranhão, tem-se no ano de 2018: o feijão com faturamento nas vendas de R \$ 67,6 milhões; o abacaxi, que arrecadou de VBP R \$31,6 milhões. o sorgo com R\$ 19,2 milhões de VBP (BRASIL, 2020c). Os produtos das lavouras permanentes, não raro representam significância econômica parca referente o faturamento estadual. Nada obstante, destaca-se a banana, a castanha de caju e o coco da baia, com, pela ordem: $\mathrm{R} \$ 69,6$ milhões; $\mathrm{R} \$ 10,1$ milhões; e $\mathrm{R} \$$ 5,5 milhões de arrecadação da comercialização desses bens agrícolas. 


\begin{tabular}{l|c|c|c|c|c|c|c}
\hline Milho & 381679 & 426203 & 535853 & 783491 & 1520047 & 682791 & 1320971 \\
\hline Soja & 660078 & 931142 & 1322363 & 1640183 & 1875792 & 1242772 & 2751206 \\
\hline Banana & 128839 & 124969 & 115311 & 107678 & 101258 & 72635 & 76345 \\
\hline Abacaxi & 39236 & 29060 & 23684 & 22747 & 31174 & 20704 & 33855 \\
\hline \multicolumn{7}{|c|}{ Produtividade (em quilogramas por hectare) } \\
\hline Arroz & 1388 & 1395 & 1238 & 1047 & 1507 & 955 & 1587 \\
\hline Algodão & 3246 & 2587 & 3288 & 4030 & 4102 & 3189 & 4102 \\
\hline Cana-de-açúcar & 60998 & 58686 & 62930 & 60801 & 57653 & 55234 & 55615 \\
\hline Mandioca & 7539 & 8111 & 7334 & 7782 & 8610 & 8257 & 8396 \\
\hline Milho & 1082 & 1170 & 1427 & 1757 & 2754 & 2052 & 3185 \\
\hline Soja & 2398 & 2431 & 2675 & 2949 & 2769 & 1586 & 2969 \\
\hline Banana & 10927 & 10768 & 10558 & 10641 & 10299 & 10465 & 11640 \\
\hline Abacaxi & 20770 & 20493 & 19444 & 19392 & 22460 & 11995 & 23031 \\
\hline
\end{tabular}

Fonte: IBGE (2020a). Elaboração: autor

Em referência às lavouras permanentes, o comportamento geral da área cultivada foi inverso dos VBP's dos produtos. Em 2003, o total foi de 31,8 mil hectares, que foi subtraído, até 2018, para 26,1 mil hectares (-17,7\%). Nos produtos dessas lavouras, a cultura da banana contribuiu para queda da área plantada, caiu de 11,7 mil para 6,5 mil hectares, o que, no período, se calcula uma percentagem negativa de 44,4\% (5,2 mil hectares).

Ainda na Tabela 1, percebe-se que nem todos dos produtos das culturas temporárias e permanentes obtiveram resultados positivos no volume da quantidade produzida. As lavouras de soja, em 2003, produziram 660 mil de toneladas de grãos e, em 2018, avançaram para 2,7 milhões, um aumento de $317 \%$, mais quatro vezes mais $(2,1$ milhões de toneladas), o que transformou o estado Maranhense no nono maior produtor nacional e o segundo no Nordeste. No mesmo intervalo, as lavouras de milho produziram a mais 1,3 milhão de toneladas, computando um aumento de 246,4\%; o Maranhão é o terceiro produtor de milho do Nordeste, com 22,5\%\% da produção. A Cana-de-açúcar obteve um crescimento relativo mais tímido em relação à soja e ao milho, partiu de 1,7 milhões toneladas para 2,4 milhões, o que significou uma expansão de $41,1 \%$ no período.

Da mesma forma, constata-se, na Tabela 1, que a cotonicultura aumentou a produção de 10,5 mil toneladas para 91,6 mil (772\%), o que ratificou o estado em segundo lugar na produção do Nordeste, perdendo apenas para o estado da Bahia. Os arrozais maranhenses, que já foram os maiores produtores do país, auferiram diminuição significativa na quantidade produzida na casa de 70\%. Quantificaram 689 mil toneladas, em 2003, e em 2018 passaram um pouco mais de 206 mil toneladas. Os bananais

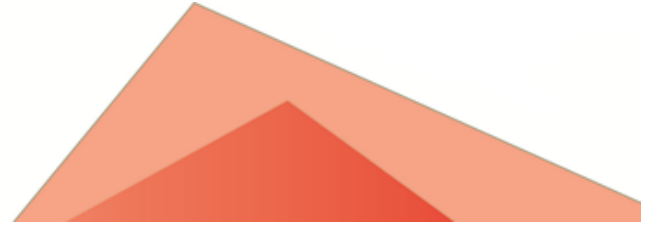




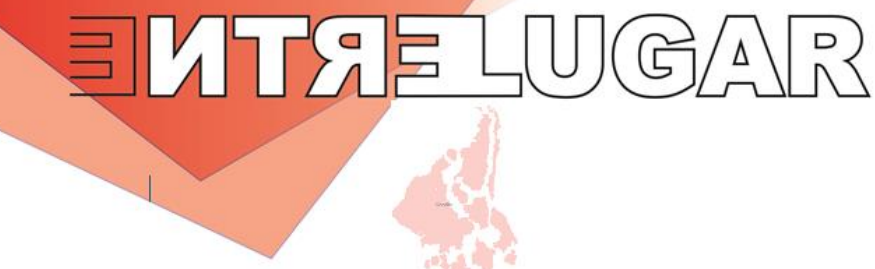

representaram, também, involução na produção, estado do Maranhão colheu 76,3 mil toneladas no derradeiro ano da sequência analisada, com apoucamento de 40,5\% no geral da série. Ao mesmo tempo, ainda, na fruticultura do abacaxi o crescimento foi negativo, na casa de $13,7 \%$, totalizando no período um decréscimo de 5,4 mil toneladas. Outra perda significativa de quantidade produzida foi nas lavouras de mandioca. Em 2003 o estado produziu 1,2 milhões de toneladas, porém em 2018 não passou de 681 mil toneladas, acumulando perda de produção de 43,2\%. Mesmo assim, o Maranhão é o sexto lugar nacional e o maior produtor de mandioca na região Nordeste.

Permanecendo na Tabela 1, a produtividade média de todos os produtos cresceu, exceto a cana-de-açúcar que caiu $8,7 \%$. Os aumentos registrados nas outras culturas, entre 2003 e 2018, foram: milho com 194,3\%; algodão com 26,3\%; soja com 23,8\%; arroz com 14,3\%; mandioca com 11,3\%; abacaxi com 10,8\%; e a banana com 6,65\%. A redução da área de lavouras permanentes provocou a diminuição global da quantidade colhida dos produtos analisados, pois o rendimento médio, entre 2003 e 2018, esteve sempre abaixo na média nacional em de $6,5 \%{ }^{12}$.

O insucesso da rizicultura em duas das três variáveis analisadas, apesar das fortes chuvas nas áreas de plantio, está associado a alta mecanização e a aplicação de herbicidas pré e pós-emergentes, e o início da irrigação nas lavouras do estado do Rio Grande do Sul, que por sua vez, proporcionou uma produtividade de quase oito toneladas por hectare, o que representa $400 \%$ a mais que as lavouras maranhenses (IBGE, 2020a) e com isso o arroz gaúcho chega mais barato no mercado do Maranhão ${ }^{13}$.

O crescimento da produção de soja, de milho, de cana-de-açúcar e de algodão não está, apenas, diretamente associado ao aumento da área plantada e da produtividade. Assim, também, são responsáveis pela produção desses bens agrícolas do Maranhão, entre outros: (i) boas condições edafoclimáticas; (ii) preços favoráveis; (iii) medidas políticoinstitucionais ${ }^{14}$; (iv) intenso desenvolvimento de inovações tecnológicas em produtos,

\footnotetext{
12 Nas lavouras permanentes no Maranhão, a produtividade foi um elemento fundamental para entender a dinâmica produtiva dos produtos agrícolas. Com exceção da castanha de caju, todos os produtos dessas lavouras estão bem abaixo da produtividade média nacional (IBGE, 2020a).

${ }^{13}$ Ademais, o MAPA, para a safra 2016/2017, reajustou o preço mínimo da saca de 50 quilos de arroz de R\$ 29,67 para R\$34,97 (CONAB, 2018), o estimulou os rizicultores gaúchos.

14 Dentre as políticas públicas do Governo Federal destacam-se: (a) Política Nacional de Segurança Alimentar e Nutricional (PNSAN); (b) Programa Nacional de Alimentação Escolar (PNAE); (c) Programa de
} 
processos; (v) crescente inserção no mercado internacional pela demanda dos países asiáticos, sobretudo, China; (vi) produtores especializados e ligados na lógica da agricultura moderna; (vii) crescente demanda por proteína animal; (viii) aumento crescente por biocombustíveis (ESPÍNDOLA; CUNHA, 2015; CUNHA; ESPÍNDOLA, 2015; 2016a; 2016b).

A produção de mandioca e de abacaxi no estado, advém de produtores que estão desestimulados por causa da baixa produtividade no primeiro e dos altos custos de produção no segundo produto, e, ainda, por causa do impulso da lucratividade das culturas mais rentáveis (milho e soja). Ademais, essas culturas possuem um path dependence desfavorável para as lavouras comerciais de outros estados, como Paraná, na mandioca, e o Pará e a Paraíba, no caso do abacaxi, pois, o desenvolvimento de inovações tecnológicas, em produtos e processos, ainda não está completo e com isso a competitividade é lenta.

Em concordância, de modo geral, com as lavouras, a pecuária maranhense, de acordo com a Figura 4, o VBP geral, entre 2009-2018, cresceu 30,7\%, passando de R\$1,3 bilhão para R \$ 1,7 bilhões, o que representa $14,1 \%$ do VBP do Nordeste. Por sua vez, segmento bovino expandiram-se em 26,7\%, saindo de R \$ 1,3 bilhão para R \$ 1,65 bilhão, conquistando $2,1 \%$ da soma do país e representa quase a totalidade $(95 \%)$ do VBP da pecuária maranhense ${ }^{15}$.

Aquisição de Alimentos (PAA); (d) Programa de Garantia de Preços para a Agricultura Familiar (PGPAF), entre outros. Para o conjunto do agronegócio, o governo brasileiro direcionou o BNDES e o Banco do Brasil como principais agentes do financiamento agropecuário (PADILHA; ESPÍNDOLA, 2015). Sobre o progressivo sistema de inovações tecnológicas, tanto de empresas privadas e públicas, sobretudo da Embrapa Soja, ver detalhes em Cunha; Espíndola (2016b).

${ }^{15}$ Em contrapartida, o VBP dos frangos obteve uma dinâmica acelerada com crescimento de 76\%, contudo, é relativamente baixo em relação à cultura bovina e não ultrapassou R \$ 18 milhões em 2018. Na cultura suína, o estado não tem expressividade e o VBP não alcançou R \$ 4 milhões. Os produtos derivados da pecuária, apenas o leite aparece, porém com pouco volume de VBP, em 2018 atingiu R\$ 64,3 milhões (BRASIL, 2020c).

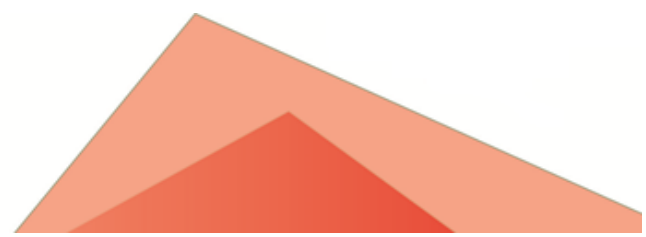


Figura 4 - Valor Bruto da Produção dos produtos da pecuária no Maranhão (Em R\$ 1000)

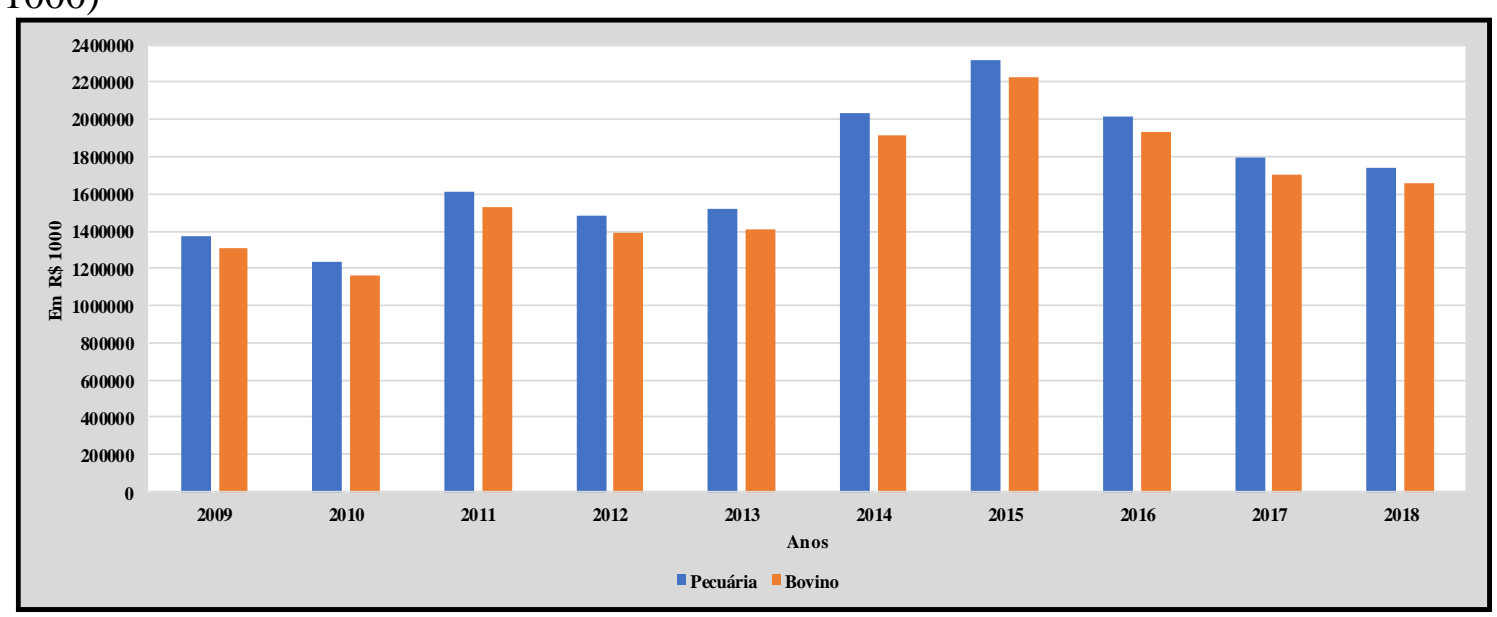

Fonte: (BRASIL, 2020c). Elaboração: autor

Desse modo, em conjunto com o aumento do VBP nos produtos do Maranhão da pecuária $^{16}$, entre 2003-2018 (Tabela 2), a variação acumulada do crescimento do número de animais abatidos no segmento bovino alcançou 38,8\%, passou de $513 \mathrm{mil}$ para 712 mil de unidades, e a quantidade produzida de carne com as carcaças foi de 38,2\%, partiu de 123 mil e alcançou 170 mil toneladas. O rebanho bovino, também, houve aumento significativo, passou 5,51 milhões para 7,79 milhões de cabeças, totalizando um aumento percentual de $41,3 \%$. Na mesma escala temporal e nas mesmas dimensões, o ramo produtivo do leite representou um aumento de 50\%, saiu de 230 milhões para 345 milhões de litros.

${ }^{16} \mathrm{Na}$ pecuária, apesar da redução das áreas de pastagens naturais e diminuição do número de produtores, a produção aumentou. Em cinco anos, o número de matrizes de suínos alojadas no estado do Maranhão caiu de 254,6 mil cabeças para 202,4 mil cabeças, o que representa uma diminuição de 20,5\%. No efetivo geral do rebanho suíno, o Maranhão diminuiu de 1,7 milhão de cabeças (com 3,2\% do total nacional), em 2003, para 1,03 milhão em 2018 (2,5\% do efetivo brasileiro) (IBGE, 2020b). O rebanho de frangos, no mesmo período, pulou de 11,4 milhões de cabeças para 12,1 milhões. No que tange à ordenha de vacas, o número de cabeças aumentou de 413,3 mil para 551,2 mil. Contudo, o número do rebanho de animais bovinos efetivos aumentou de 5,5 milhões de cabeças, em 2003, para 7,8 milhões, em 2018 (IBGE, 2020b).

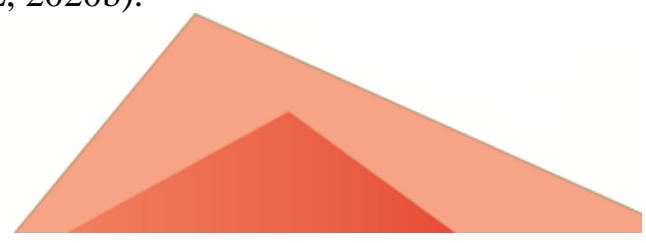


Tabela 2 - Abate de animais e quantidade produzida de carcaças e leite no Maranhão

\begin{tabular}{l|l|l|l|l|l|l|l}
\hline & $\mathbf{2 0 0 3}$ & $\mathbf{2 0 0 6}$ & $\mathbf{2 0 1 0}$ & $\mathbf{2 0 1 2}$ & $\mathbf{2 0 1 4}$ & $\mathbf{2 0 1 6}$ & $\mathbf{2 0 1 8}$ \\
\hline Rebanho bovino (em mil cabeças) & 5514 & 6613 & 6979 & 7490 & 7758 & 7653 & 7793 \\
\hline Abate bovino (em mil cabeças) & 513 & 734 & 589 & 683 & 833 & 776 & 712 \\
\hline Qt. pro. bovino (em mil toneladas) & 123 & 171 & 134 & 158 & 191 & 182 & 170 \\
\hline Qt. pro. leite (em milhões litros) & 230 & 341 & 375 & 381 & 393 & 371 & 345 \\
\hline
\end{tabular}

Fonte: IBGE (2020b)

Essa vitalidade Maranhão acompanhou o dinamismo na pecuária nacional que proporcionou uma nova divisão territorial do trabalho, com o aumento de participação dos estados, pois decorre do déficit de milho, o que tem forçado as agroindústrias de carnes para novas áreas. Com isso, fizeram-se novas inversões na agroindústria de carnes e seus derivados para o Nordeste e Norte do país, que contribuíram para a explicar essa configuração territorial, entre elas: (i) economia de escala e de envergadura (megaabatedouros, novos sistemas criatórios, menor e outro tipo de produtor); (ii) economia de custo de transação na aquisição de insumos; (iii) proximidade dos mercados consumidores em potencial de crescimento; (iv) estratégias de fusões e aquisições, etc. (ESPÍNDOLA, 2009; 2016).

Além do crescimento do VBP, da produção e dos índices de produtividade, os produtos da agropecuária do Maranhão apresentaram dinâmica recente em suas exportações. Sendo assim, conforme a Figura 5, foram responsáveis por mais de 51,2\% das exportações totais do estado e quase $2 \%$ das exportações totais dos agronegócios brasileiros (US\$ 101,1 bilhões). Entre 2003-2018, as receitas auferidas no mercado externo obtiveram um crescimento de 13,3 vezes. No mesmo período, as exportações do agronegócio passaram de US\$ 146,5 milhões para US\$ 1,9 bilhão, enquanto as exportações totais maranhenses cresceram cerca de 5,18 vezes, saindo de US\$ 739 milhões para US\$ 3,8 bilhões. 


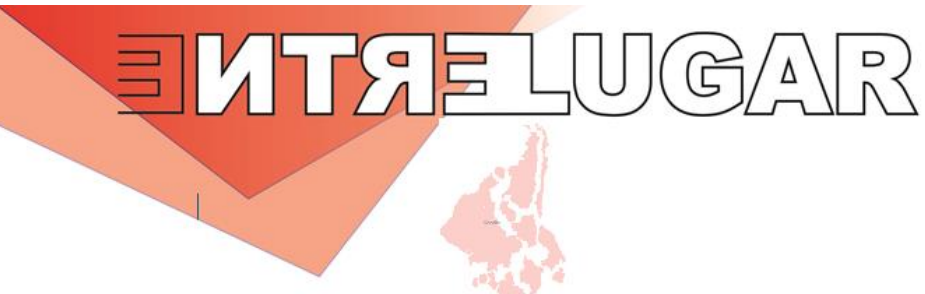

Figura 5- Exportações totais e da agropecuária do estado da Maranhão

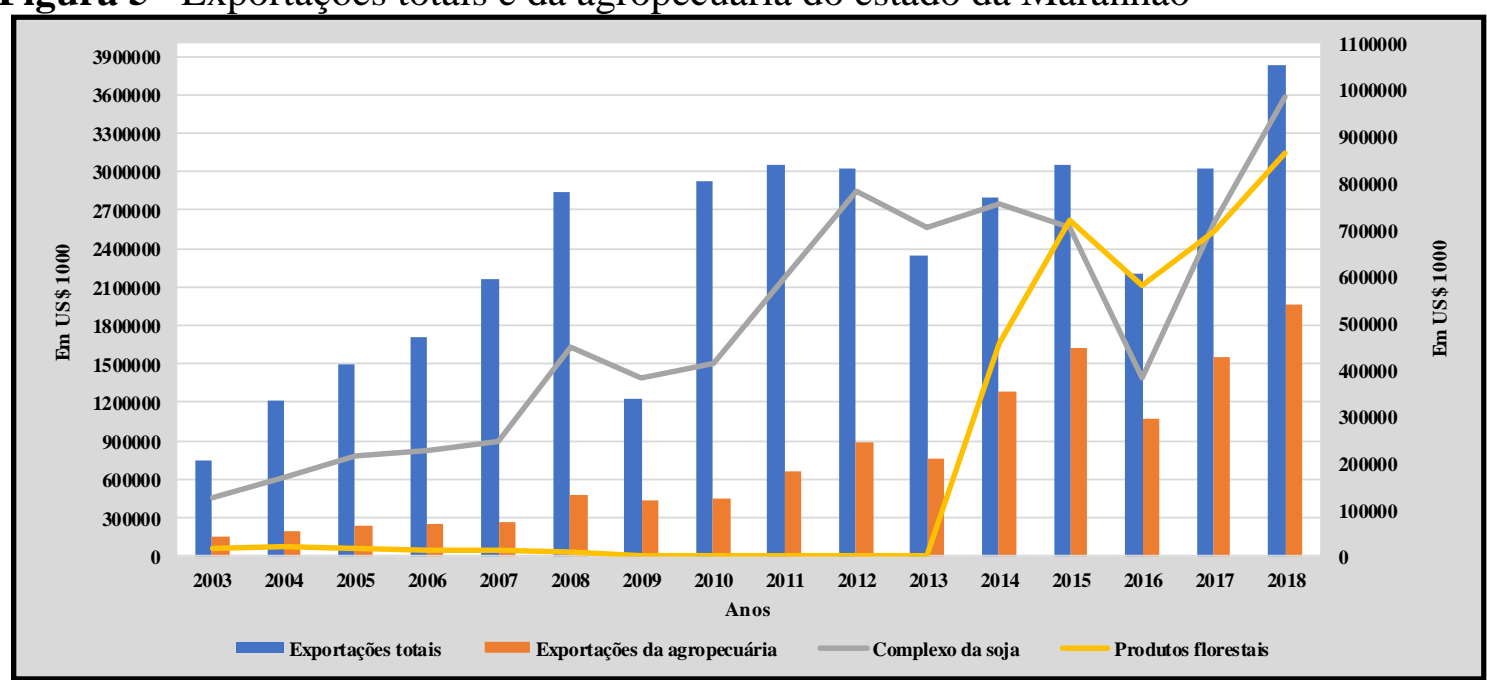

Fonte: Brasil (2020a; 2020b). Elaboração: autor

Em termos de produtos, a Figura 5 demonstra que as exportações do complexo da soja alcançaram uma porcentagem de 678,7\%, crescendo de US\$ 126,4 milhões para US\$ 984,3 milhões, um aumento de US\$ 858 milhões. Nos produtos florestais ${ }^{17}$ as vendas externas, entre 2003 e 2013 foram praticamente inexistentes no estado do Maranhão, contudo, a partir de 2014, após a inauguração da fábrica da Suzano Papel e Celulose, os valores dos exportados saíram de US\$ 456 milhões para US\$ 862 milhões em 2018. Em apenas cinco anos as exportações de produtos florestais cresceram 89\%. Esses dois complexos de produtos são responsáveis por $94,1 \%$ e concentram-se, principalmente, em produtos como: soja em grãos (99\% do complexo) e; celulose (98\% dos produtos florestais).

Os desempenhos da produção, da produtividade e das exportações da agropecuária do estado maranhense manifestam-se territorialmente, pois a produção, embora concentrada, sobretudo em lavouras temporárias e a pecuária no segmento bovino, de

\footnotetext{
${ }^{17}$ Na silvicultura, o estado do Maranhão aumentou seu market share, entre 2003 e 2018: 24,7 vezes em carvão vegetal, saindo de 15,4 mil para 380,5 mil de toneladas. Em 2014, madeira em tora obteve uma produção de 2,01 milhões de metros cúbicos, e em 2018 passou para 3,2 milhões de metros cúbicos. Esse mesmo produto, no mesmo período, manteve uma dinâmica elástica de 75,6\% no faturamento do VBP, partindo de R \$ 324,6 milhões para R \$ 570 milhões (IBGE, 2020c). No extrativismo maranhense, no período entre 2003 e 2018, destacam-se o carvão vegetal saindo de 474,4 mil para 107,1 mil toneladas e o babaçu, que também apresentou dinâmica negativa, passando de 104,4 mil para 47,1 mil toneladas. Esses dois produtos representam 87,8\% do VBP do extrativismo do Maranhão (IBGE, 2020c).
}

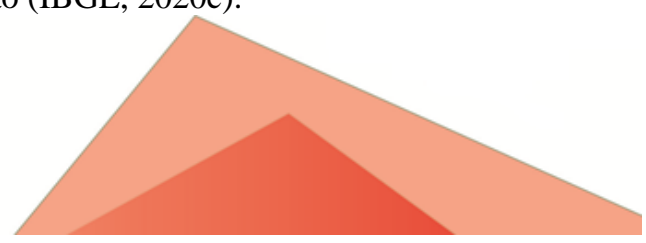




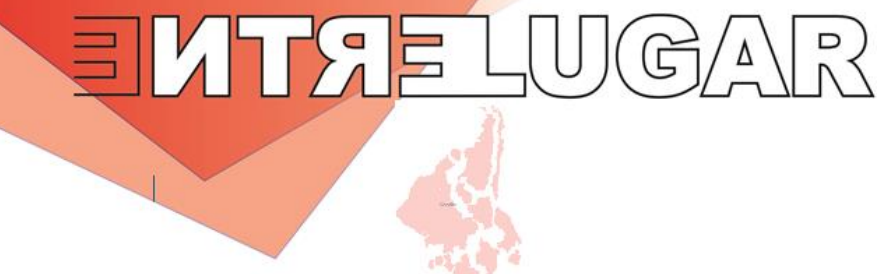

maneira desigual, promovendo, ao longo de sua evolução, concentrações produtivas territoriais a qual se analisará na próxima seção.

\section{NOVO ARRANJAMENTO TERRITORIAL DA AGROPECUÁRIA DO MARANHÃO}

No estado do Maranhão, as mesorregiões ${ }^{18}$, denominadas e classificadas por IBGE (2012), apresentaram, entre 2003-2018, comportamentos não semelhantes, entretanto, com a mesma propensão de crescimento dinâmico em termos de valor adicionado bruto da produção, porém com involução de área plantada, com exceção da região Sul. Em 2018, 98,5\% da área plantada total do estado representava as lavouras temporárias, contra menos de 1,4\% da área destinada às lavouras permanentes (IBGE, 2020a).

Dessa maneira, entre as mesorregiões do estado maranhense, conforme a Figura 6, a mesorregião Sul, a única que obteve crescimento positivo, manteve-se em primeiro lugar no uso do solo para as lavouras temporárias. O acréscimo, entre 2003 e 2018, ficou em 199,7\% (incremento de 731 mil hectares), saindo de 366 mil para 1,09 milhão de hectares. Não obstante, a mesorregião Leste, segunda maior em aproveitamento da terra, diminuiu de 307 mil para 269 mil de hectares, um índice negativo de 12,3\% (menos 38 mil hectares). No mesmo período, seja na terceira maior mesorregião (Oeste Maranhense), seja na quarta (Centro Maranhense), as culturas temporárias também decresceram suas áreas plantadas, respectivamente: saíram de 316 mil e 252 mil para 201 mil e 142 mil hectares, totalizando taxas não positivas de 36,3\% (115 mil hectares) e $43,6 \%$ (110 mil).

\footnotetext{
${ }^{18}$ Segundo Cunha e Farias (2019, p. 145), “o IBGE apresentou uma nova divisão regional no Brasil vinculada aos processos sociais, políticos e econômicos sucedidos em território nacional desde a última versão da Divisão Regional do Brasil, publicada na década de 1990. As unidades mesorregionais e as microrregionais recebem, respectivamente, os nomes de regiões geográficas intermediárias e regiões geográficas imediatas. O recorte dessas incorpora as mudanças ocorridas no Brasil ao longo das últimas três décadas. O processo socioespacial recente de fragmentação/articulação do território brasileiro, em seus mais variados formatos, pode ser visualizado em vários estudos desenvolvidos no IBGE. O recurso metodológico utilizado na elaboração da presente Divisão Regional do Brasil valeu-se dos diferentes modelos territoriais oriundos de estudos pretéritos, articulando-os e interpretando a diversidade resultante". Nesta seção foram considerados os novos critérios; porém, foram adotados os nomes das cinco mesorregiões: Norte Maranhense; Oeste Maranhense; Centro Maranhense; Leste Maranhense; Sul Maranhense.
}

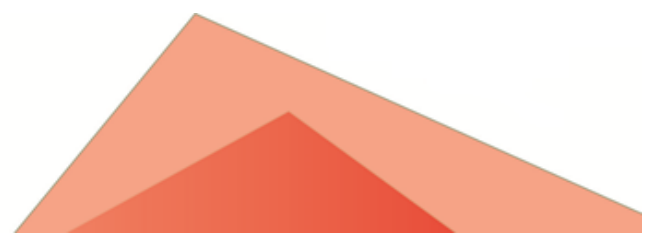




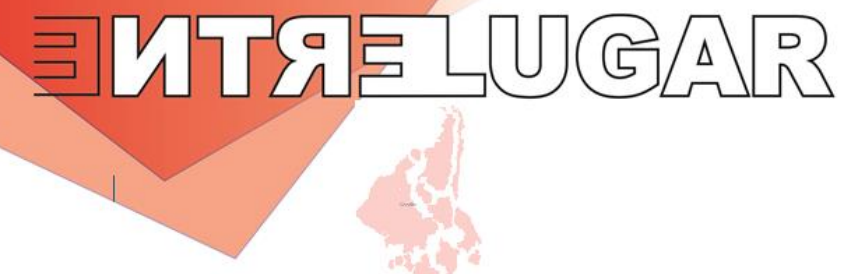

Figura 6 - Área plantada de lavouras temporárias das mesorregiões do Maranhão (hectares)

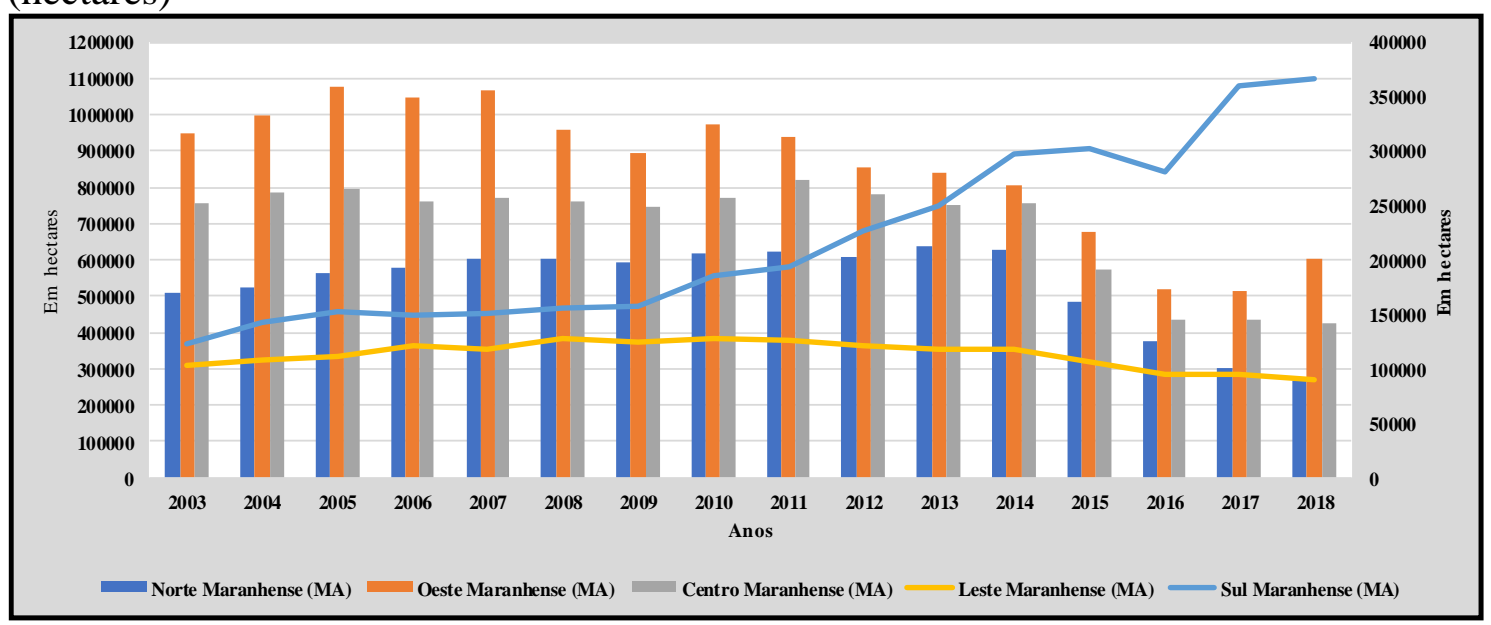

Fonte: IBGE (2020a). Elaboração: autor

Além disso, ainda na Figura 6, a mesorregiões Norte Maranhense não conseguiu elevar sua área plantada. No período da análise, sai de 170 mil para 89 mil hectares, totalizando um decréscimo de 47,6\%, o que representa perda de 81 mil hectares ${ }^{19}$.

Na variável VAB (Figura 7), todas as mesorregiões do estado do Maranhão tiveram variação positiva. A mesorregião Sul (polarizada pelo município de Balsas), entre 2003-2018, obteve uma evolução nas receitas de VAB com culturas temporárias de $\mathrm{R} \$ 557,2$ milhões para $\mathrm{R} \$ 3,2$ bilhões, representando, em termos percentuais, um acréscimo de $477 \%$. O Leste, região do município de Chapadinha, aumentou o valor em 222,8\% na série analisada, saiu de um VAB de $\mathrm{R} \$ 211,4$ milhões para $\mathrm{R} \$ 682,4$ milhões. Essa tendência dinâmica foi escoltada pelas demais mesorregiões, pela ordem decrescente de aferição de VAB no período: Oeste (polarizada pelo município de Imperatriz) cresceu 143,4\%, saindo de $\mathrm{R}$ \$ 217,1 milhões para atingir R \$ 528,4 milhões; Centro Maranhense (região do município de Grajaú), cresceu 108,8\%, saiu de receitas na produção agrícola de $\mathrm{R} \$ 128,6$ milhões para $\mathrm{R}$ \$ 268,5 milhões; a mesorregião Norte

19 Como comentado, houve uma involução na área plantada das lavouras permanentes na ordem de 17,7\%. No período entre 2003 e 2018, ocorreu competitividade negativa nas seguintes mesorregiões maranhenses: Oeste - 26,3\%; Centro - 32,3\%; Leste- 24,4\%; Sul - 3,8\%. A mesorregião Norte Maranhense foi a única que apresentou um aumento na ordem de 5,7\% (IBGE, 2020a).

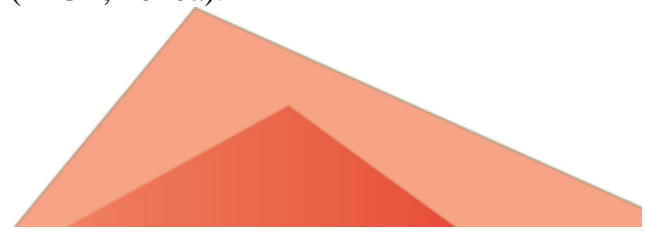


Maranhense (polarizada pelo município de São Luís), variou positivamente cerca de 46,5\%, totalizando, em 2018, um VAB de R\$ 166,1 milhões ${ }^{20}$.

Figura 7 - Valor adicionado bruto de Produção das lavouras temporárias das mesorregiões do Maranhão (Mil Reais)

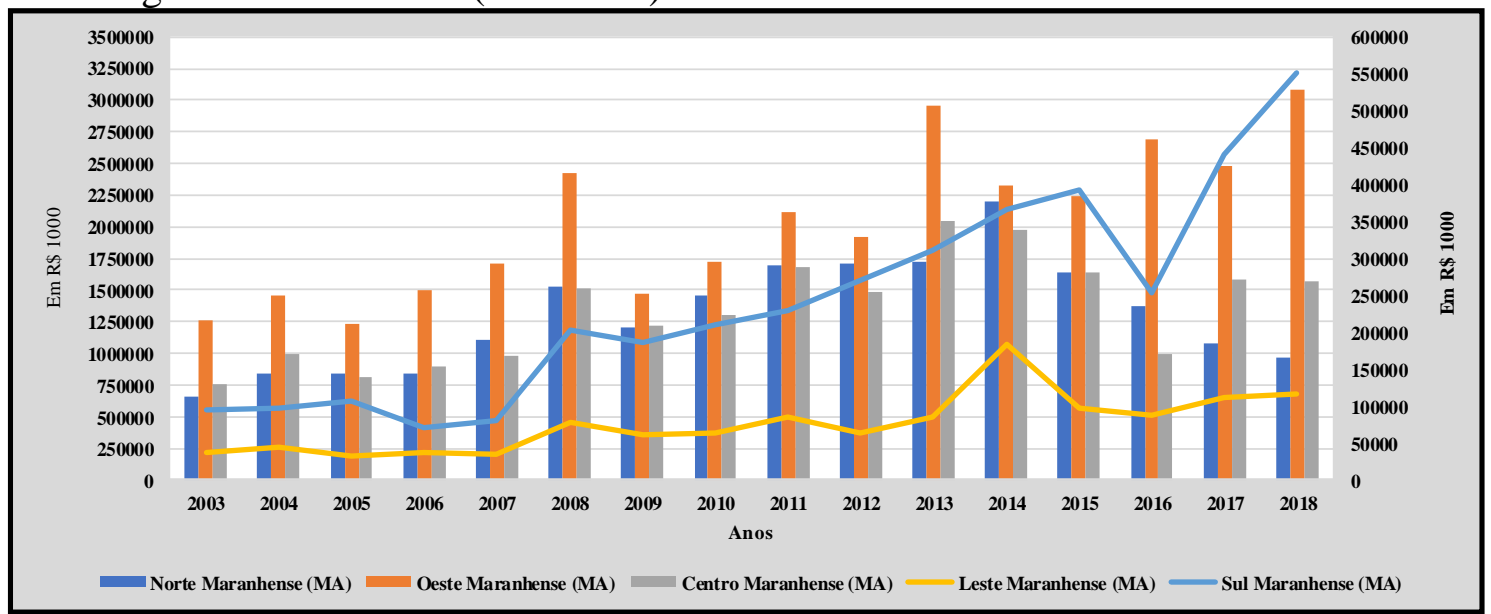

Fonte: IBGE (2020a). Elaboração: autor

Essa dinâmica mesorregional do estado do Maranhão explicita-se (Tabela 3), especialmente, devido ao aumento da produção dos bens agrícolas provenientes de lavouras temporárias, com exceção do arroz e mandioca. A mesorregião Sul Maranhense é responsável pelas maiores safras de soja, milho, cana-de-açúcar e algodão. Sozinha é encarregada por: 72,5\% (1,9 milhão de toneladas) da produção de soja estadual, 1,7\% da produção nacional e 17,2\% da produção do Nordeste brasileiro; 67,4\% (890 mil de toneladas) da colheita estadual de milho, $1,1 \%$ da safra nacional e $15,2 \%$ da produção da regional; $52,6 \%$ da produção estadual de cana-de-açúcar e 5\% da colheita nordestina; e por $100 \%$ da quantidade produzida de algodão. Em matéria de variação percentual de quantidade produzida, entre 2003-2018, essa mesorregião obteve aumento na soja de $213,3 \%$ e no milho $861,5 \%$, ganhos competitivos de 798,5\% no algodão e estagnação produtiva na cana-de-açúcar na ordem positiva de $1,68 \%$.

\footnotetext{
${ }^{20}$ O estado do Maranhão aumentou, entre 2003 e 2018, seu VAB nas lavouras permanentes em 12,08\%, saindo de $\mathrm{R} \$ 84,3$ milhões para $\mathrm{R} \$ 94,4$ milhões (IBGE, 2020a). A mesorregião Centro Maranhense possui $41,8 \%$ de todo VAB do estado nessas lavouras, aumentou de $\mathrm{R} \$ 37,3$ milhões para $\mathrm{R} \$ 39,5$ milhões, acumulando 5,8\% no período de 2003 a 2018 (IBGE, 2020a).
}

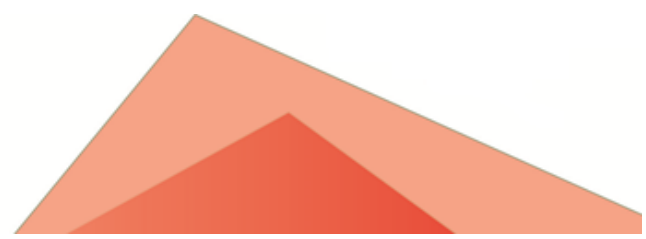


Tabela 3 - Produção dos produtos das lavouras temporárias nas mesorregiões do Maranhão (toneladas)

\begin{tabular}{c|c|c|c|c|c|c}
\hline \multirow{2}{*}{$\begin{array}{c}\text { Mesorregiões do } \\
\text { Maranhão }\end{array}$} & \multicolumn{7}{|c}{$\mathbf{2 0 0 3}$} \\
\cline { 2 - 8 } & Arroz & Algodão & Cana & Mandioca & Milho & Soja \\
\hline Norte Maranhense (MA) & 60751 & - & 5652 & 462706 & 22610 & - \\
\hline Oeste Maranhense (MA) & 183973 & - & 134155 & 445439 & 112791 & - \\
\hline Centro Maranhense (MA) & 159683 & 49 & 42807 & 111103 & 86933 & 3606 \\
\hline Leste Maranhense (MA) & 214645 & 222 & 263195 & 206916 & 66737 & 19183 \\
\hline Sul Maranhense (MA) & 69999 & 10293 & 1257278 & 15026 & 92608 & 637289 \\
\hline & \multicolumn{7}{|c}{$\mathbf{2 0 1 8}$} \\
\hline Norte Maranhense (MA) & 33310 & - & 10812 & 306213 & 15076 & - \\
\hline Oeste Maranhense (MA) & 21722 & - & 100481 & 156892 & 191280 & 333941 \\
\hline Centro Maranhense (MA) & 77245 & - & 75687 & 67760 & 120585 & 60236 \\
\hline Leste Maranhense (MA) & 51070 & - & 962889 & 122697 & 103678 & 361095 \\
\hline Sul Maranhense (MA) & 23630 & 91654 & 1278115 & 27456 & 890352 & 1995934 \\
\hline
\end{tabular}

Fonte: IBGE (2020a)

A Tabela 3 mostra, ainda, que a mesorregião Leste Maranhense apresentou variações positivas na produção de soja (1.790\%), saindo de 19,1 mil para 361 mil de toneladas, o que representa $13,1 \%$ da colheita da soja no estado. Na produção de canade-açúcar, essa mesorregião apresentou forte impulso dinâmico crescendo $266 \%$, subindo de 263,1,4 mil para 962,8 mil de toneladas. A quantidade produzia nas lavouras de milho cresceu cerca de 55\% no período em destaque, pulando de 66,7 mil para 103,6 mil toneladas. Não obstante, essa mesma mesorregião apresentou taxas negativas na produção de arroz $(76,2 \%)$, decrescendo de 214,6 mil para 51 mil toneladas e mandioca (40,7\%), caindo de 206,9 mil até 122,6 mil toneladas.

A mesorregião do estado que também apresentou tendência dinâmica na produção de milho e de soja foi a Oeste. A taxa de crescimento, entre 2003 e 2018, atingiu $69,7 \%$, saindo de 112,7 mil para 191,2 mil de toneladas no milho e no segundo produto que sequer aparecia nas estatísticas, contudo, em 2018, colheu das lavouras 333,9 mil toneladas de grãos. Entretanto, apresentou inclinação negativa para as culturas de: arroz com queda de $88,1 \%$; mandioca com diminuição de $64,7 \%$, passando de 445,4 mil para 156,8 mil de toneladas; e cana-de-açúcar com taxa recessiva de $25 \%$, minimizando a colheita de 134,1 mil para 100,4 mil toneladas.

Desperta atenção, ainda na Tabela 3, o índice positivo de $1.573 \%$ na produção de grãos de soja na mesorregião Centro Maranhense, em que, em 2003, foram colhidos 


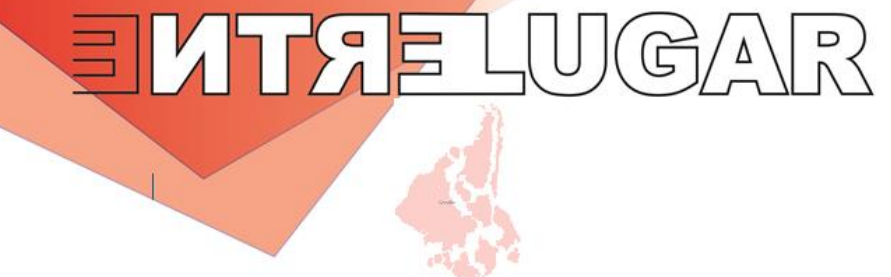

3,6 mil de toneladas, e, em 2018, passou para 60,3 mil. Houve avanço considerável na cultura do milho entre o período em análise, passou de 86,9 mil para 120,5 mil toneladas, amontoando acréscimo de 38,6\%. A colheita da cana-de-açúcar passou de 42,8 mil para 75,6 mil toneladas, totalizando uma taxa geral de crescimento, no período, de 76,6\%. No entanto, as culturas do arroz e da mandioca caíram, respectivamente, cerca de 51,6\% e 39\%. Continuando na Tabela 3, a mesorregião Norte Maranhense possui pouca propensão a produzir grãos. Destaca-se, sobretudo, a produção de mandioca, uma vez que, mesmo em forte declínio produtivo, essa mesorregião permanece em primeiro lugar na produção estadual dessa cultura. A colheita decresceu $33,8 \%$, saindo de 462,7 mil toneladas para 306,2 mil toneladas na última safra do período.

Com base no exposto, pode-se afirmar que vem ocorrendo no estado do Maranhão um processo de reconfiguração regional da produção dos produtos das lavouras, caracterizado pelas dinâmicas competitivas de: concentração; desconcentração; especialização; disseminação; e exclusão. A soja, milho e cana-deaçúcar sofrem desconcentração, especialização; disseminação. $\mathrm{O}$ arroz está em processo de disseminação guiada por uma exclusão produtiva. A mandioca está em movimento de concentração lastreada em exclusão e substituição de áreas produtivas. O algodão por ser uma cultura relativamente recente, em parâmetro de agricultura moderna no estado, se encontra em evolução concentrada. Esses processos vêm redefinindo a distribuição regional das lavouras maranhenses e provendo uma especialização produtiva territorial, fundamentalmente, na soja, no milho e na cana-de-açúcar ${ }^{21}$.

Em relação à pecuária, como se depreende da Figura 8, a concentração, especialização e disseminação territorial apresentam-se de forma acentuada no rebanho

\footnotetext{
${ }^{21}$ Com referência as lavouras permanentes, a maior alteração ocorreu na cultura da banana através de dois processos: concentração e exclusão produtivas territoriais. Apesar da queda geral na produção de banana no estado em 40,7\%, ainda assim, a mesorregião Centro Maranhense produziu 36 mil toneladas em 2018, que representa 47,2\% do total estadual (IBGE, 2020a). No referente aos produtos da silvicultura, o carvão vegetal o processo dominante foi a concentração territorial nas mesorregiões Oeste e Centro Maranhense, no qual concentram $95,6 \%$ da produção. Na produção de madeira em tora para celulose, o Oeste Maranhense produziu, em processo de concentração, 65,2\% da safra de 2018 do Maranhão, porém não impediu que houvesse um processo de disseminação territorial nas demais mesorregiões (IBGE, 2020c). Ademais, no extrativismo, tanto o carvão vegetal como o babaçu estão em processo de desconcentração em conjunto com exclusão territorial (IBGE, 2020c).
}

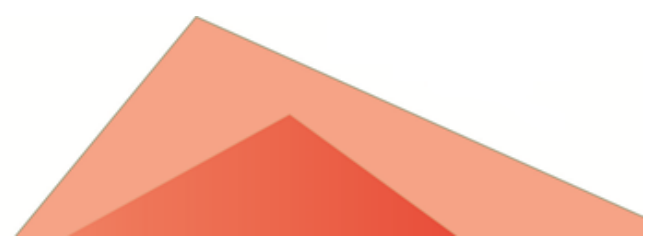


de bovinos. A mesorregião Oeste Maranhense, em 2003, possuía 2,4 milhões e, em 2018, aumentou para 3,3 milhões de cabeças, acumulando no período índice de 37,5\%, a região mantém o maior rebanho bovino do Maranhão (42,3\%), detém 1,5\% do rebanho nacional e $11,8 \%$ do efetivo bovino do Nordeste. O Centro Maranhense, na criação de bovino, entre 2003 e 2018, conservou-se em segundo lugar estadual $(25,8 \%)$, saindo de 1,2 milhão para 1,99 milhão, totalizando no geral uma taxa de $65,8 \%$, o que representa $7,3 \%$ do rebanho nordestino. A terceira mesorregião com o maior contingente bovino do estado, a Sul Maranhense, apresentou tendência crescente no mesmo período, saiu 750 mil cabeças para 1,08 milhão, somando um acréscimo de $45 \%$.

Figura 8 - Rebanho de bovinos nas mesorregiões do estado do Maranhão - 2003-2018
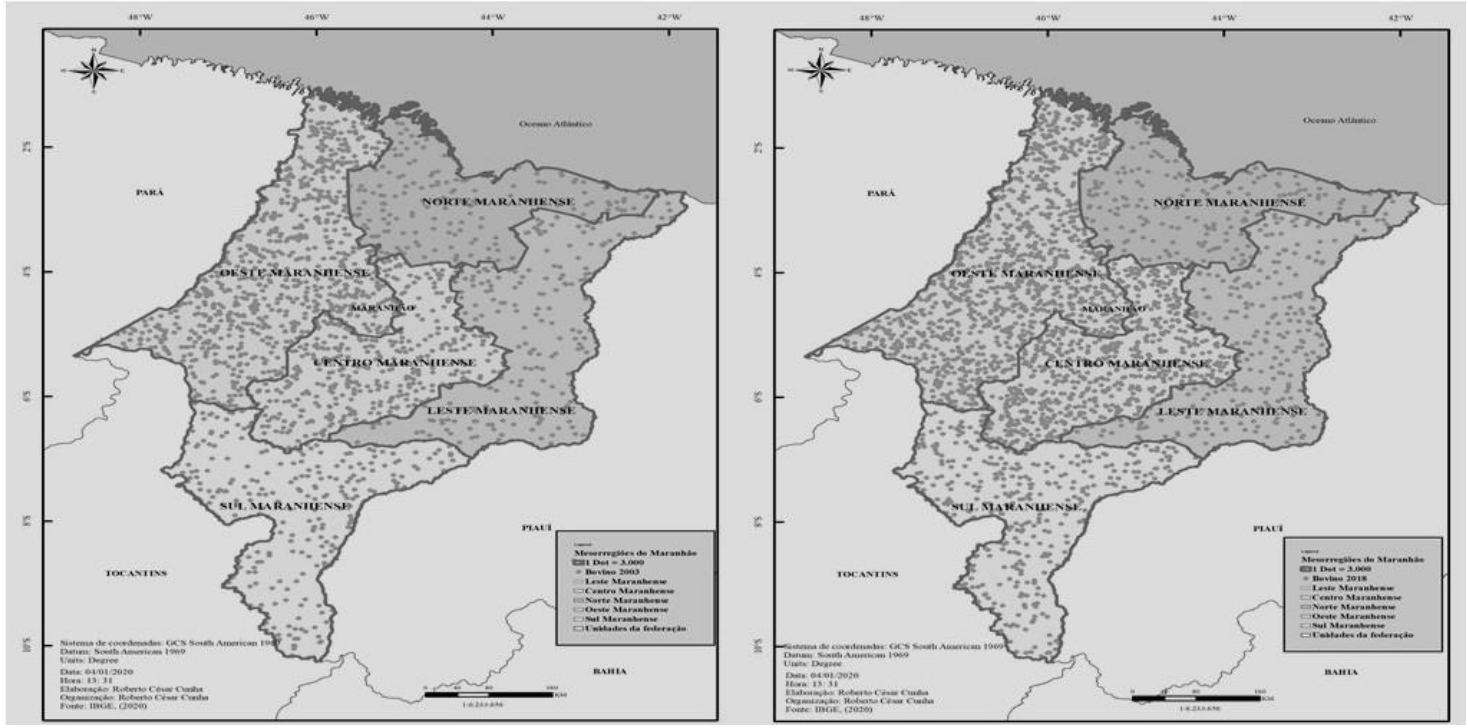

Fonte: IBGE (2020b). Elaboração: autor

Percebe-se, na mesma Figura 8, que o rebanho bovino se disseminou territorialmente mais ainda. Em 2003, a mesorregião Leste Maranhense detinha 606 mil cabeças, em 2018, aumentou para 828 mil. Um crescimento absoluto de 222 mil de cabeças, o que rende 10,6\% do gado bovino estadual. A mesorregião Norte Maranhense possuía 503 mil cabeças, passou para 587 mil, o que correspondeu a 16,7\% de

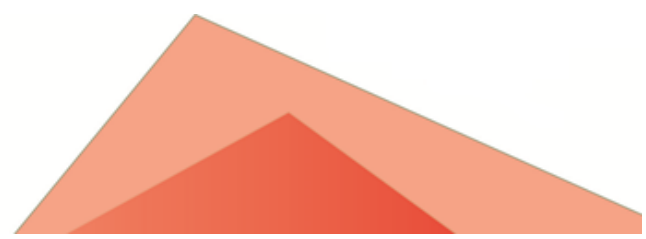


crescimento no intervalo em análise, rendendo 84 mil cabeças a mais e participando com 7,5\% do total do rebanho do Maranhão.

Quando se refere aos produtos derivados da pecuária, sobretudo o leite, a produção aumentou em todas as mesorregiões, com exceções da Leste Maranhense e Norte Maranhense que se mostraram estáveis; no entanto, esse produto se territorializou em processo concentração e disseminação. A região Oeste Maranhense que, em 2003, era o maior produtor, com 128,1 milhões, passou para 182,8 milhões de litros de leite em 2018, atingindo taxa positiva de $42,7 \%$, representando $52,9 \%$ do total do estado. $\mathrm{Na}$ mesorregião Sul Maranhense, onde a cultura do leite mais se disseminou, em 2003, produziu 24,6 milhões de litros, em 2018, aumentou para 51,3 milhões, perfazendo uma taxa acumulada de $108,5 \%$. A Centro Maranhense aumentou a produção de leite de 47,4 milhões para 79,3 milhões de litros. Esse aumento representou taxa de 67,2\% entre 2003 e 2018, o significa 22,9\% da produção leiteira do Maranhão (IBGE, 2020b).

\section{CONSIDERAÇÕES FINAIS}

Foi demonstrado que o processo de ocupação do território do estado do Maranhão resultou na constituição de duas estruturas produtivas na agropecuária: uma caracterizada com forças produtivas principalmente ligadas à agricultura pautada na grande propriedade privada, com relações de produção apoiada na escravidão e a outra formou uma estrutura econômica e social apoiada em forças produtivas ligado a pecuária com relações de sociais apoiada num conjunto de renda trabalho e renda produto. Contudo, essas duas estruturas, ao longo de sua trajetória evolutiva, sobretudo pós-1970, passaram por profundas transformações, que originaram uma agropecuária dinâmica e internacionalizada.

Argumentou-se que, no período compreendido entre 2003-2018, as alterações manifestaram-se na evolução do Valor Bruto da Produção da agropecuária. Entretanto, a elevação das rendas geradas se assemelhou com o aumento da área plantada de produtos, como milho, soja, algodão e cana-de-açúcar, além da redução das áreas de pastagens. Em contrapartida, ocorreu diminuição da área plantada no arroz, na

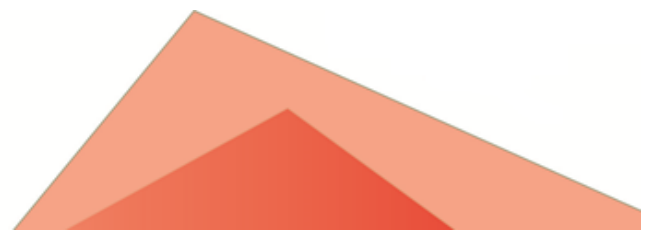


mandioca, banana e abacaxi. A redução da área de pastagens não provocou diminuição da produção total. A redução da produção manifestou-se nas lavouras dos produtos que diminuíram suas áreas de plantadas. Esses aumentos da produção decorreram das boas condições climáticas, preços favoráveis, medidas político-institucionais e pelo aumento da produtividade.

Na pecuária maranhense, sobretudo o ramo bovino, vem ganhando participação relativa e absoluta no conjunto do market share da região Nordeste do Brasil, o que aponta para uma nova divisão territorial do trabalho. Ademais, a despeito de a estrutura produtiva da agropecuária maranhense apresentar-se pouco diversificada, demonstrouse que vem ocorrendo um processo de reconfiguração regional da produção agropecuária, caracterizado pela concentração, desconcentração, especialização, disseminação e exclusão territoriais.

Esses processos estão acelerando a especialização produtiva territorial. A desconcentração, disseminação e especialização territoriais se fazem, principalmente, no caso da soja, do milho e da cana-de-açúcar onde, em algumas regiões do estado, o incremento anual de área e da produção tem sido significativo, substituindo áreas de pastagens, de arroz e de mandioca. Nas culturas do arroz e da mandioca, o primeiro produto está em processo de disseminação guiada por uma exclusão produtiva e o segundo está em movimento de concentração lastreada em exclusão e substituição de áreas produtivas. E em característica de evolução concentrada se encontra a cotonicultura maranhense.

A concentração, disseminação, especialização territoriais apresentam-se de forma acentuada no rebanho de bovino. Concentrada e especializada territorialmente, a mesorregião Oeste Maranhense detém 43,3\% da criação de bovino no estado. A região Centro Maranhense mostrou, também, uma concentração na faixa de $25 \% \mathrm{em}$ associação com a Sul Maranhense com 13,9\%. Essas três áreas de criação de gado bovino concentram e especializam mais de $82 \%$ do total do rebanho estadual. Contudo, essa concentração não foi barreira para evitar a disseminação territorial, pois houve aumento significativo na criação de bovinos nas mesorregiões Leste e Norte do Maranhão.

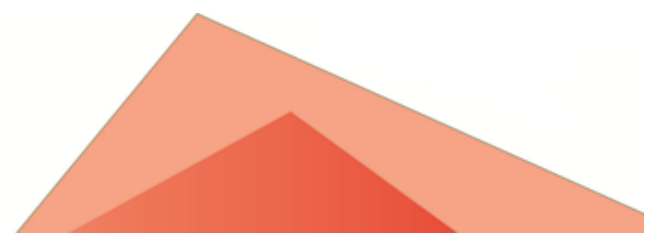


Os processos de concentração e disseminação territoriais ocorreram com os produtos derivados da pecuária, sobretudo, o leite. Houve aumento na produção de leite em todas as mesorregiões do estado. O Oeste Maranhense ficou com 52,9\% do total, a Centro Maranhense computou 22,9\% e a mesorregião Sul maranhense produziu 14,8\% do leite do estado. Somente essas três mesorregiões concentram mais de $90 \%$ da produção leiteira do Maranhão.

Por fim, cada momento do processo histórico de desenvolvimento, com sua estrutura econômica, social, política, cultural, dentro de uma formação socioespacial, tem uma significação particular. Por isso, como foi explanado, numa determinada área geográfica "não tem funções permanentes, nem um nível de forças produtivas fixos e relações de produção e de propriedade imutáveis. Interagem e evolui no processo" (SANTOS, 1977, p. 84). Dito isso, as estruturas dos sistemas produtivos, as relações territoriais e sociais representam interação entre o novo e o velho, com domínio do primeiro. No entanto, esse poder de dominação, das novas estruturas, das novas configurações territoriais não se realiza por completo e não se pode cair em determinismos específicos territoriais, pois não há vocação, o capital se transforma no tempo e espaço (SANTOS, 1977).

\section{Referências}

ABREU, C. de. Capítulos de história colonial e Caminhos antigos e povoamento do Brasil. Brasília, editora UNB, 1982.

ANDRADE, M. C. Nordeste. Espaço e Tempo. Petrópolis: Vozes, 1995.

BARBOSA, N. Dez anos de Política Econômica. In: SADER, E. (Org.). 10 anos de governos pós-neoliberais no Brasil: Lula e Dilma. São Paulo; Rio de Janeiro: Boitempo; Flacso, 2013. p. 63-101.

BIELSCHOWSKY, R. Estratégia de Desenvolvimento e as Três Frentes de Expansão no Brasil: um desenho conceitual. Texto para Discussão. n. 1828, Brasília: IPEA. abr. 2013.0 p. 1-27. Disponível em: 〈http://www.ipea.gov.br/portal/images/stories/PDFs/TDs/td_1828.pdf >. Acesso em: 06 jan. 2020. 
BRASIL, Ministério da Economia, Industria, Comércio Exterior e serviços. Balança comercial. 2020a. Disponível em: < http://www.mdic.gov.br/balanca-comercial>. Acesso em: 01 jan. 2020.

Estatísticas de comércio exterior do agronegócio brasileiro. 2020b. Disponível em: <http://sistemasweb.agricultura.gov.br/pages/AGROSTAT.html>. Acesso em: 01 jan. 2020.

Ministério da Agricultura, Pecuária e Abastecimento. Valor Bruto da Produção Agropecuária. 2020c. Disponível em: < http://www.agricultura.gov.br/>. Acesso em: 03 jan. 2020.

CARDOSO, C. Pastos Bons. Rio de Janeiro: IBGE, 1947. (Série Municípios Maranhenses).

CARVALHO, C. O Sertão. Rio de Janeiro: Obras Scientíficas e Literárias, 1924.

CASTRO, A. B. de. 7 ensaios sobre a economia brasileira.Vol 2. 3 ed. Rio de Janeiro, Forense Universitária, 1980.

CHOLLEY, A. Observações sobre alguns pontos de vista geográficos. Boletim Geográfico, Rio de Janeiro, n. 180, p. 267-276, 1964.

CONAB. Companhia Nacional de Abastecimento. Governo reajusta preços mínimos das culturas de verão. Brasília, 2018. Disponível em: $<$ https://www.conab.gov.br/ultimas-noticias/1782-governo-reajusta-precos-minimosdas-culturas-de-verao-20160708>. Acesso em: 01 jan. 2020.

CONTINI, E. et al. Evolução recente e tendências do agronegócio. Revista de Política Agrícola, Brasília, CONAB, ano XV, n. 1, jan.-fev.-mar. 2006, p. 5-28. Disponível em: $\langle$ https://seer.sede.embrapa.br/index.php/RPA/article/view/475>. Acesso em: 10 jan. 2020 .

COUTINHO, M. A revolta de Bequimão. São Luís. Instituto Géia, 2004.

CUNHA, R. C. Ocupação e desenvolvimento das duas formações sócio espaciais do Maranhão. Cadernau- Cadernos do Núcleo de Análises Urbanas, Rio Grande, v. 8, n. 1, p.133-152, jan. 2015.

CUNHA, R. C.; ESPÍNDOLA, C. J. A geoeconomia da produção de soja no sul do Maranhão: características sociais e territoriais. Revista da ANPEGE, São Paulo, ANPEGE, n. 16, v.11, p. 37-65, jul./dez., 2015.

Dinâmica econômica da cadeia produtiva da soja no sul do Maranhão.

Boletim Gaúcho de Geografia, Porto Alegre, v. 43, n. 2, p. 187-207, $2016 \mathrm{a}$. 
A Relevância do progresso técnico na consolidação da cadeia produtiva da soja no Sul do estado do Maranhão (Brasil). Geografia (Londrina), v. 25. n. 1. p. 87106, jan./jun., 2016b.

; FARIAS, F. R. Dinâmica produtiva e ordenamento territorial dos agronegócios do Mato Grosso do Sul pós-2003. Geosul, Florianópolis, v. 34, n. 71, p.130-153, mai 2019.

ESPÍNDOLA, C. J. A dispersão territorial dos investimentos do agronegócio de carne. Anais de Geografia Econômica e Social, v. 2, Florianópolis: GCN, 2009. p. 251-281. Disponível em: <http://cadernosgeograficos.ufsc.br/aquisicao/revista-geografiaeconomica/>. Acesso em: 20 jan. 2020.

A dinâmica geoeconômica do agronegócio brasileiro de carnes e soja. In: LAMOSO, L. P. (Org.). Temas do desenvolvimento econômico brasileiro e suas articulações com o Mato Grosso do Sul. Curitiba: Íthala, 2016. p. 19-53.

CUNHA, R. C. C. A dinâmica geoeconômica recente da cadeia produtiva de soja no Brasil e no Mundo. Geotextos, v. 11, n. 1, p. 217-238, Salvador, UFBA, 2015.

FARIA, L.A.E. Sobre o conceito de valor agregado: uma interpretação. Ensaios FEE, Porto Alegre, v.3, n.2, p. 109-118,1983.

FURTADO, C. Formação econômica do Brasil. 34. ed. São Paulo: Companhia das Letras, 2007.

GIL, A. C. Métodos e técnicas de pesquisa social. Atlas: São Paulo, 1994.

GONÇALVES, J. S. Agricultura sob a égide do capital financeiro: passo rumo ao aprofundamento do desenvolvimento dos agronegócios. Informações econômicas, São Paulo, IEA, v. 35, p. 7-36, abr. 2005. Disponível em: <http://www.iea.sp.gov.br/out/publicacoes/pdf/tec1-0405.pdf $>$. Acesso em: $10 \mathrm{jul}$. 2020.

IBGE. Instituto Brasileiro de Geografia e Estatística. Divisão regional do Brasil em mesorregiões e microrregiões geográficas. v. I. Rio de Janeiro, 2012. Disponível em: $<$ http://biblioteca.ibge.gov.br/visualizacao/monografias/GEBIS\%20\%20RJ/DRB/Divisao\%20regional_v01.pdf>. Acesso em: 04 jan. 2020.

Pesquisa Agrícola Municipal. Rio de Janeiro, 2020a. Disponível em:< https://sidra.ibge.gov.br/pesquisa/pam/tabelas >. Acesso em: 06 jan. 2020.

Pesquisa Pecuária Municipal. Rio de Janeiro, 2020b. Disponível em:< https://sidra.ibge.gov.br/pesquisa/ppm/quadros/brasil/2016>. Acesso em: 07 jan. 2020.

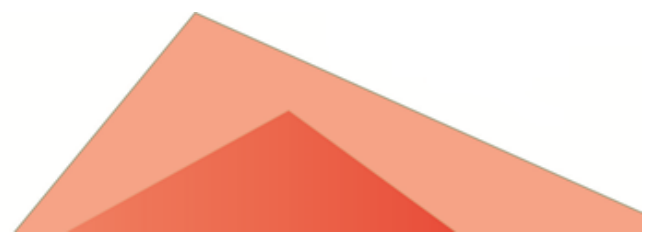


Pesquisa da Produção Vegetal e da Silvicultura. Rio de Janeiro, 2020c. Disponível em: 〈https://sidra.ibge.gov.br/pesquisa/abate/tabelas >. Acesso em: 03 jan. 2020.

. Produto Interno Bruto dos Municípios. Rio de Janeiro, 2020d. Disponível em: 〈https://sidra.ibge.gov.br/tabela/5938>. Acesso em: 03 jan. 2020.

Censo Agropecuário 2017. Rio de Janeiro, 2020e. Disponível em: <https://sidra.ibge.gov.br/pesquisa/censo-agropecuario/censo-agropecuario-2017>. Acesso em: 02 jan. 2020.

- Cidades. Rio de Janeiro, 2020f. Disponível em: < https://sidra.ibge.gov.br/pesquisa/pevs/quadros/brasil/2017>. Acesso em: 03 jan. 2020.

MALUF, R. S. J. A expansão do capitalismo no campo: o arroz no Maranhão. 1977. 142 f. Dissertação (Mestrado em Economia) - Instituto de Economia, Unicamp, Campinas, 1977.

MEIRELES, Mário M. História do Maranhão. 3. ed. São Paulo: Siciliano, 1960.

PADILHA, W.; ESPÍNDOLA, C. J. Prodecoop e Procap-agro e o crescimento das cooperativas agroindustriais da região sul. In: ENANPEGE, 11., 2015, Presidente Prudente. Anais... . Presidente Prudente: Edufgd, 2015. v. 1, p. 6187- 6198.

PRADO JR, Caio. Formação do Brasil contemporâneo. Cia das Letras, São Paulo, 2011.

RANGEL, I. A singularidade do pensamento de Ignácio Rangel. V. 2 São Luís: IMESC, 2008.

SANTOS, M. Sociedade e espaço: A formação social como teoria e como método. Boletim Paulista de Geografia, São Paulo, v. 54, p. 81-100, jun. 1977.

VIVEIROS, Jerônimo. História do comércio do Maranhão-1612/1895. São Luís: Associação Comercial do Maranhão/Lithograf, 1954.

Recebido em dezembro de 2019.

Aceito para publicação em março de 2020.

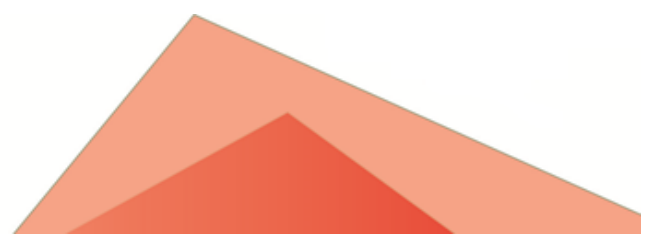

